\title{
Diagnostics of new species of Neotropical Tischeriidae (Lepidoptera), with the first record of Coptotriche Walshingham from South America
}

\author{
JONAS R. STONIS ${ }^{1,2,7}$, ARŪNAS DIŠKUS ${ }^{1,2}$, ANDRIUS REMEIKIS ${ }^{1}$, LILIANA KATINAS ${ }^{3}$, \\ NIXON CUMBICUS TORRES ${ }^{4}$, JACK SCHUSTER ${ }^{5} \&$ JULIA PUPLESYTE-CHAMBERS ${ }^{6}$ \\ ${ }^{1}$ Nature Research Centre and Baltic-American Biotaxonomy Institute, Akademijos St. 2, Vilnius 08412, Lithuania. \\ ${ }^{2}$ Vytautas Magnus University, K. Donelaičio St. 58, Kaunas 44248, Lithuania. \\ ${ }^{3}$ División Plantas Vasculares, Museo de La Plata, Paseo del Bosque s/n, 1900 La Plata, Argentina. \\ ${ }^{4}$ Universidad Técnica Particular de Loja, San Cayetano Alto s/n, Loja, Ecuador. \\ ${ }^{5}$ Systematic Entomology Laboratory, Universidad del Valle de Guatemala, Guatemala City, Guatemala. \\ ${ }^{6}$ DAR Peru, Derecho Ambiente y Recursos Naturales, Jirón Huáscar 1415, Jesús Maria, Lima, Perú. \\ ${ }^{7}$ Corresponding author. E-mail: stonis.biotaxonomy@gmail.com
}

\begin{abstract}
We describe seven new Neotropical species of Tischeriidae: Astrotischeria dondavisi Stonis \& Diškus, sp. nov., A. bacchariphaga Diškus \& Stonis, sp. nov., A. guatemalica Diškus \& Stonis, sp. nov., A. sanjosei Stonis \& Diškus, sp. nov., A. truncata Diškus \& Stonis, sp. nov., Coptotriche parvisacculata Diškus \& Stonis, sp. nov. and C. carmencita Stonis \& Diškus, sp. nov. We report the discovery of Coptotriche Walsingham in South America and provide the following new host-plant records for the Neotropical Tischeriidae: Terminalia australis Cambess. (Combretaceae), Baccharis latifolia (Ruiz \& Pav.) Pers., and B. emarginata (Ruiz \& Pav.) Pers. (Asteraceae). We update the biology of Astrotischeria ochrimaculosa Diškus, Stonis \& Vargas with the discovery that Wissadula (Malvaceae) is a new, verified host plant. The new species are illustrated with photographs of the adults, male and, if available, female genitalia, and the leaf mines. We expect broader distributions of tisheriid species in South America inferred from known host-plant distributions.
\end{abstract}

Key words: Astrotischeria, Astrotischeria ochrimaculosa, Coptotriche, Neotropics, taxonomy, trumpet leafminer moths

\section{Introduction}

Tischeriidae, trumpet moths or trumpet leafminer moths, are among the most interesting of the microlepidopteran groups from an evolutionary point of view. They represent a distinct family of leaf-mining Lepidoptera with uniquely modified morphological and ecological characterizations (Puplesis \& Diškus 2003; Diškus \& Stonis 2015; Xu et al. 2017, 2018; Stonis et al. 2017, 2018, 2019). They are characterized by a highly specialized lifestyle of mining in assimilative tissues of plants (Figs 3-5, 8, 9, 12-18) and occur in many terrestrial habitats. Because of species endemism and a high degree of stenophagy, these insects can be a tool for assessing biodiversity richness of habitats and provide data on evolutionary processes (Diškus \& Stonis 2012). Nevertheless, trumpet moths are still probably among the least studied lepidopteran groups in tropical areas, including Central and South America. The study of the tischeriid fauna in the Neotropics began in the late nineteenth to early twentieth century with descriptions of some species from the Caribbean, southwestern Mexico, Guyana, Ecuador and Peru (for a detailed review see Stonis et al. 2019). On the basis of our previous field experience in the countries of Latin America, we hypothesize that Tischeriidae might make up a significant portion of the Neotropical fauna of leaf-mining insects. Prior to this study, we counted 28 described and 55 undescribed tischeriid species from the region. In this paper we describe seven selected new species in order to have their names and host-plant data available for our on-going analyses.

\section{Materials and methods}

Descriptions of the new species treated in this paper are based on material deposited in the collection of the Zoological Museum, Natural History Museum of Denmark, Copenhagen (ZMUC). 
Collecting methods and protocols for species identification and description are outlined in Puplesis \& Diškus (2003) and Stonis et al. (2014, 2018). Permanent preparations on microscope slides were photographed and studied using a Leica DM2500 microscope and Leica DFC420 digital camera. Adults were photographed using a Leica S6D stereoscopic microscope with an attached Leica DFC290 digital camera, except for Figs 25, 26, 30, 31, 42, 44-46, which were photographed using a Lomo MBS10 stereoscopic microscope and a temporarily attached Samsung Galaxy S7 cellular telephone with a camera.

\section{Descriptions of new species}

\section{Coptotriche parvisacculata Diškus \& Stonis, sp. nov.}

(Figs 1-5, 22, 49-56, 112-114)

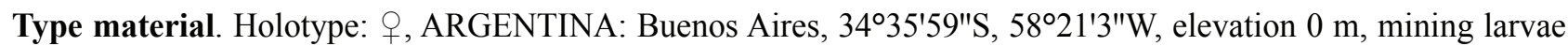
on Terminalia australis Cambess. (Combretaceae), 2.iii.2019, ex pupa iii.2019, field card no. 5305, A. Diškus,

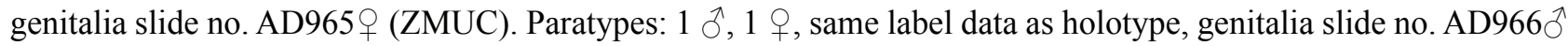
(from an adult in pupal skin) (ZMUC).

Diagnosis. External characters are not sufficient for species identification. In the male genitalia, the combination of a distinctly truncated vinculum (Fig. 51) and a uniquely shaped phallus with weakly developed spines (Fig. 55) distinguishes $C$. parvisacculata from other Coptotriche species, including the South Asiatic C. terminaliae Puplesis \& Diškus. In the female genitalia, the elaborate prela (Fig. 112) and bulbous corpus bursae (Fig. 114) appear to be unique to this species. These female characters may not remain valid for species differentiation because females of many other Coptotriche species are unknown. The host plant, Terminalia australis, and its distinctive leaf mines (Figs 3-5) make this species unique in the Neotropical fauna.

Description. Male. Known only from an adult in a pupal skin; for external description see female below. Genitalia (Figs 49-56) with capsule about $455 \mu \mathrm{m}$ long. Uncus with two very large lateral lobes (Figs 49, 53, 54). Valva wide, undivided (Figs 52, 53), about $505 \mu \mathrm{m}$ long (excluding the basal process); transtilla short, with distinctive sublateral processes (Fig. 50); basal process of valva short (Figs 52, 53). Anellus membranous, indistinctive. Diaphragma little spined. Vinculum truncated (Fig. 51). Phallus about $530 \mu \mathrm{m}$ long, strongly broadened in distal one-fourth, with weakly developed spines (Figs 55, 56).

Female (Fig. 22). Forewing length 3.2-3.3 mm; wingspan 7.3-7.4 mm $(\mathrm{n}=2)$.

Head. Face, labial palpus and pecten yellowish cream; frontal tuft and collar pale grey proximally, yellowish cream distally; antenna distinctly longer than one-half length of forewing; flagellum pale grey to grey cream, at base ochre cream.

Thorax. Tegula, thorax, and forewing concolorous, glossy ochre, with some black scales along forewing margins and at apex; black scales without purple iridescence; fringe grey, with incomplete and inconspicuous fringe line; forewing underside covered with dark grey scales, except forewing apex ochre cream; no androconia. Hindwing pale grey on upper side and underside, without androconia; fringe pale grey. Legs metallic grey, with some yellowish cream scales and bristles.

Abdomen. Dark grey on upper side, grey proximally, yellowish cream distally on underside; no anal tufts. Genitalia (Figs 112-114) about $1780 \mu \mathrm{m}$ long. Ovipositor lobes large with short, stout and darker, modified setae ('peg setae') (Fig. 112); area between ovipositor lobes indistinct, with tiny papillae and some short setae. Second pair of lobes, lateral and anterior to ovipositor lobes, much larger than ovipositor lobes, bearing very long slender setae, without peg setae (Fig. 113). Posterior apophyses much longer than anterior ones (Figs 112, 113); prela comprised of three pairs of projections (Figs 112, 113). Corpus bursae bulbous (Fig. 114), without pectinations or signum. Accessory sac wide; ductus spermathaecae large, without coils.

Bionomics (Figs 1-5). Host plant is Terminalia australis Cambess. (Combretaceae) (Figs 1, 2). Larvae mine leaves in early March; based on pupae and vacant leaf mines, mining may start as early as February; voltinism unknown. The larva is pale green with a pale brown head and dark green intestine. The blotch mine (Figs 3-5) is irregular, usually pale, but with little irregularly deposited frass; fully developed mines may bend (distort) the mined leaf (Fig. 5). Adults occur in March. 

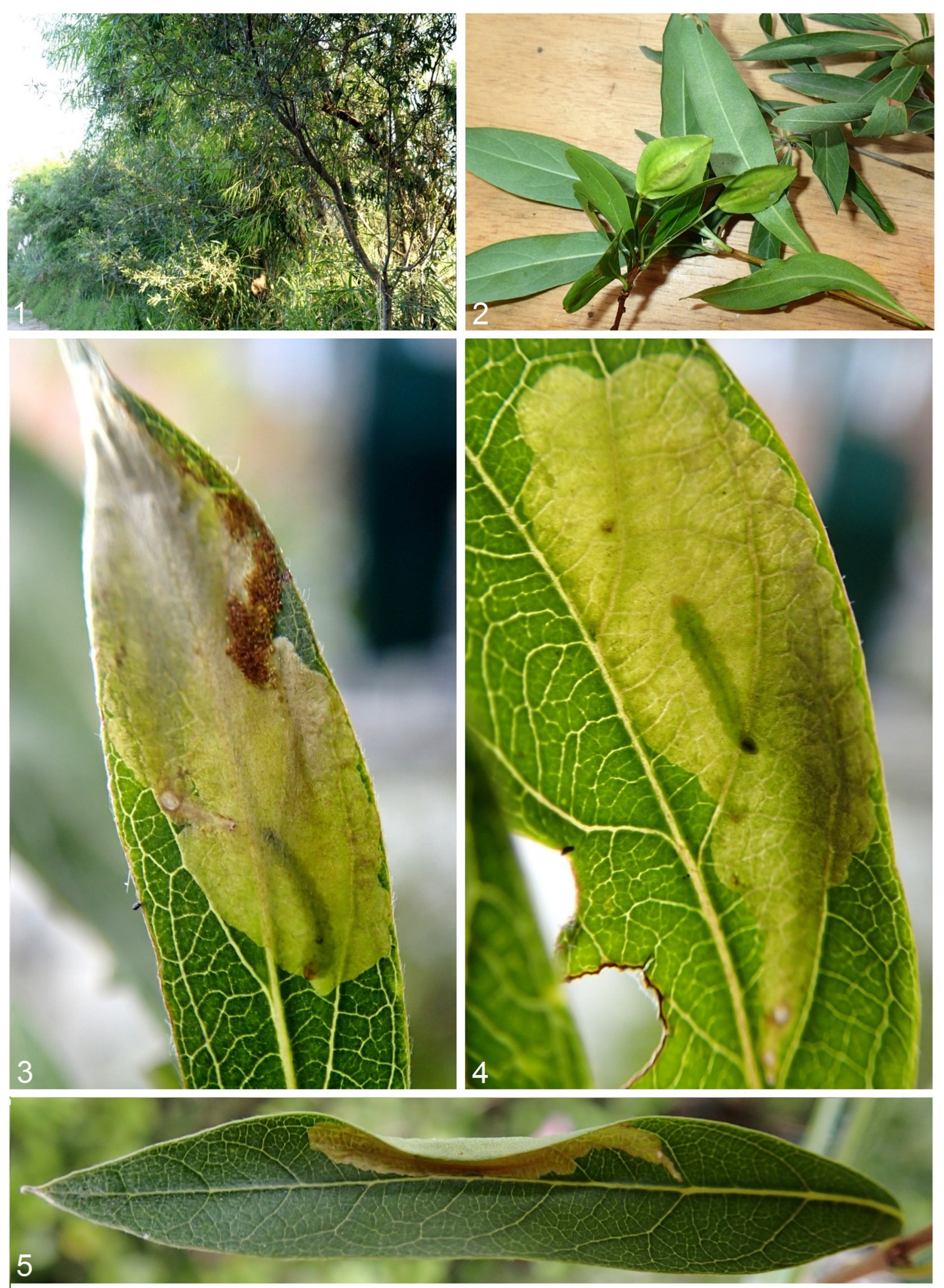

FIGURES 1-5. Bionomics of Coptotriche parvisacculata Diškus \& Stonis, sp. nov. 1, 2, host plant, Terminalia australis Cambess., Combretaceae; 3-5, leaf mines. 



FIGURES 6-9. Bionomics of Astrotischeria bacchariphaga Diškus \& Stonis, sp. nov. 1, host plant, Baccharis emarginata (Ruiz \& Pav.) Pers., Asteraceae; 2, same, B. latifolia (Ruiz \& Pav.) Pers., Asteraceae; 8, 9, leaf mines. 


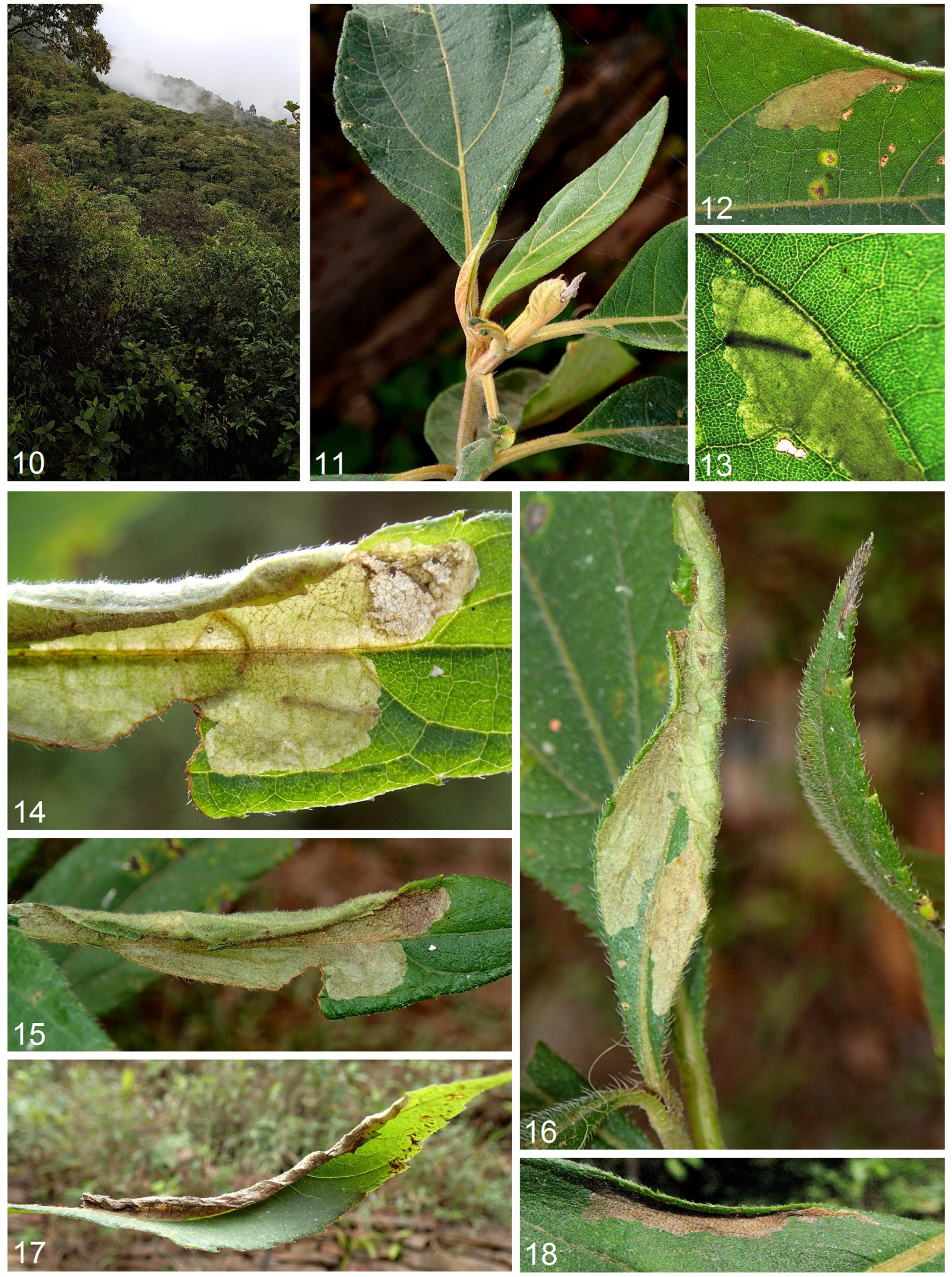

FIGURES 10-18. Bionomics of Astrotischeria truncata Diškus \& Stonis, sp. nov. 10, habitat, the Nor Yungas; 11, unidentified host plant, possibly aff. Eupatorium sp., Asteraceae (see Remarks); 12-18, leaf mines. 

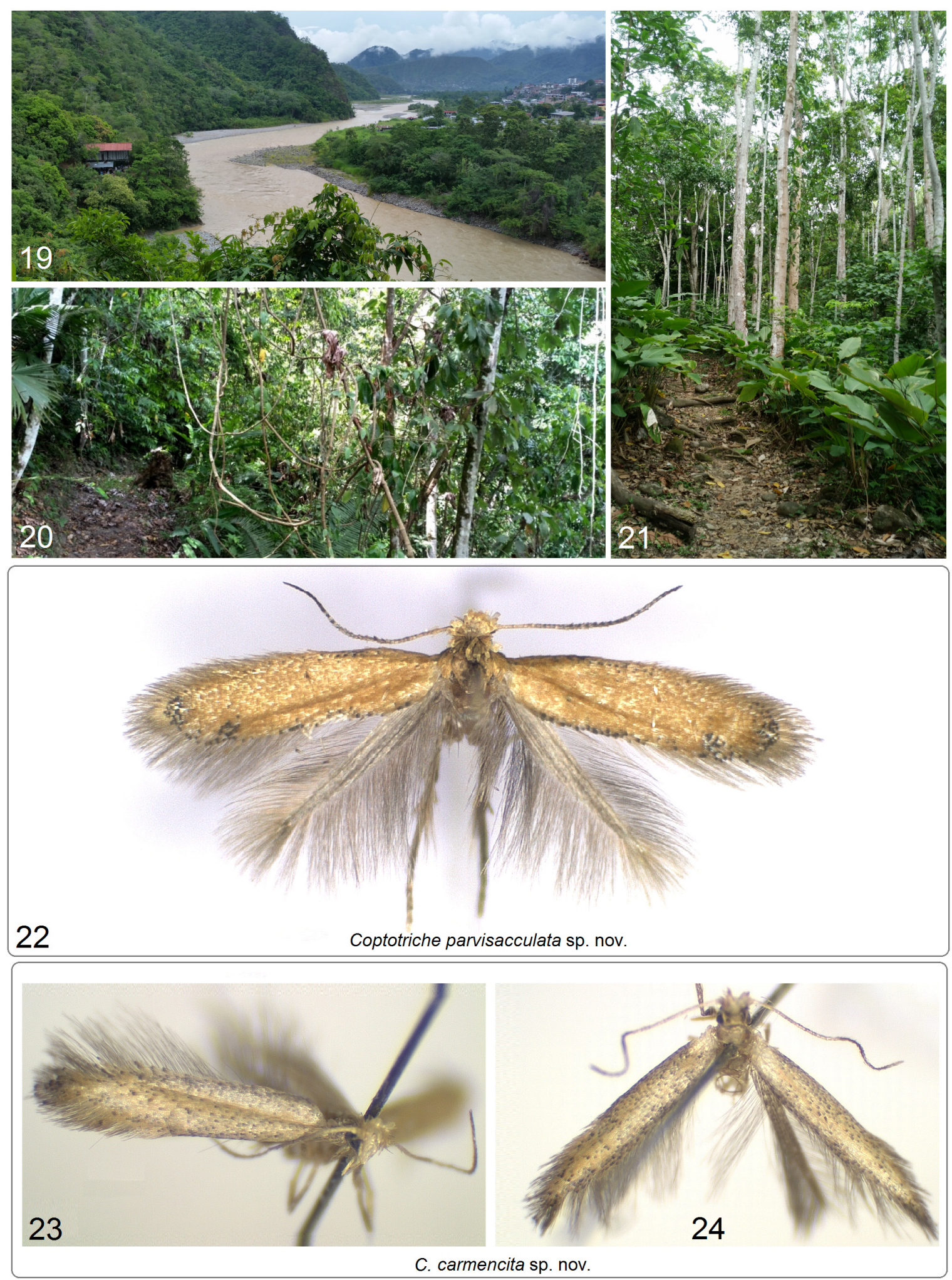

FIGURES 19-24. Type locality and adults of new species. 19, type locality of Coptotriche carmencita Stonis \& Diškus, sp. nov., Astrotischeria dondavisi Stonis \& Diškus, sp. nov., and A. sanjosei Stonis \& Diškus, sp. nov., Peruvian selva alta in La Merced, Junín Region, central Peru, with an approximate view to Fundo San José ecological park at the top right corner; 20, 21, selva alta, Ecological Park Fundo San José; 22, female, holotype of Coptotriche parvisaccula Diškus \& Stonis, sp. nov.; 23, 24, male, holotype of C. carmencita Stonis \& Diškus, sp. nov. 
Distribution. The species is known from the single locality, Buenos Aires, Argentina, but the host plant has a much broader distribution (see Discussion).

Etymology. The species name is derived from the Latin parvus (short or small) and sacculus (a distal part of vinculum) referring to the unique, small and truncated vinculum in the male genitalia.

\section{Coptotriche carmencita Stonis \& Diškus, sp. nov.}

(Figs 23, 24, 57-62, 115-120)

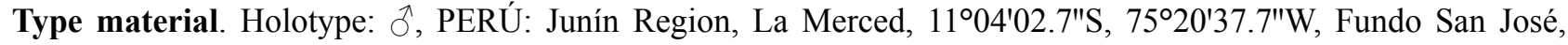
840-900 m, at light, 8-17.v.2018, leg. J. R. Stonis \& S. R. Hill, with participation of J. Puplesyte-Chambers, genitalia slide no. AD992 (ZMUC). Paratypes: $1 \hat{\jmath}$ (with abdomen missing), 1 + , same label as holotype, genitalia slide no. AD993 (ZMUC).

Diagnosis. External characters are not sufficient for species identification. In the male genitalia, the combination of a short, slender, triangular vinculum (Fig. 61), weakly developed spines on the phallus (Fig. 62), strongly spined diaphragma (Fig. 61), and a membranous, wrinkled anellus (Fig. 59) distinguishes C. carmencita from all known Coptotriche species. In the female genitalia, the combination of a bulbous accessory sac (Fig. 116), very large and elaborated ductus spermathecae (Fig. 120), and long corpus bursae (Fig. 116) distinguishes the new species from all known congeneric species.

Description. Male (Figs 23, 24). Forewing length 2.6-2.7 mm; wingspan 5.6-5.8 $\mathrm{mm}(\mathrm{n}=2)$.

Head. Face, labial palpus; frontal tuft, and collar concolorous, yellow cream to yellow-ochre; antenna distinctly longer than one-half length of forewing; flagellum glossy, greyish cream to yellow cream.

Thorax. Tegula, thorax, and forewing concolorous, glossy, ochre-yellow, sparsely speckled with grey scales, and with some purple iridescence, particularly distinct along forewing dorsum; fringe grey, with incomplete and inconspicuous fringe line, comprised of black scales; forewing underside densely covered with pale grey to dark grey scales, with slight purple iridescence, without spots or androconia. Hindwing glossy white to pale grey (depending on angle of view), without androconia; fringe ochre cream to pale grey. Legs very glossy, cream, with some grey and black grey scales on upper side.

Abdomen. Grey cream, with distinct metallic gloss on upper side, pale grey, distally yellow-ochre or whitish cream on underside; anal tufts inconspicuous, yellowish cream. Genitalia (Figs 57-62) with capsule about $365 \mu \mathrm{m}$ long. Uncus with two very large lateral lobes (Figs 58, 60). Valva broad, undivided (Figs 58, 61), about $275 \mu \mathrm{m}$ long (excluding the basal process); transtilla short (Fig. 57); basal process of valva short (Fig. 58). Anellus membranous, wrinkled (Fig. 59). Diaphragma spined (Fig. 61). Phallus about $515 \mu \mathrm{m}$ long, strongly broadened in distal third, with weakly developed spines (Fig. 62).

Female. Externally similar to male.

Genitalia (Figs 115-120) about $1800 \mu \mathrm{m}$ long. Ovipositor lobes large (Fig. 117) with short, stout and darker, modified setae ('peg setae') (Fig. 119); area between ovipositor lobes indistinct, with tiny papillae and some short setae. Second pair of lobes, lateral and anterior to ovipositor lobes, much smaller than ovipositor lobes, but bearing very long slender setae, without stout, modified peg setae. Posterior apophyses longer than anterior ones (Figs. 115, 116); prela comprised of three pairs of projections (Fig. 117). Corpus bursae long and narrow (Fig. 116), without pectinations or signum. Accessory sac bulbous (Fig. 116); ductus spermathaecae very large, elaborate, but without coils (Figs 116, 120); utriculus absent or not preserved.

Bionomics. The host plant is unknown. Adults occur in May, and fly to light.

Distribution. The species is known from the single locality, La Merced, Junín Region, central Peru, at an elevation of about $900 \mathrm{~m}$, from the "selva alta" (Figs 19-21).

Etymology. The species name "carmencita" is a diminutive version of the feminine name Carmen. The name (instead of the correct Latin version "carmencitae") was chosen as an arbitrary combination of letters and in honor of señora Carmen Brocq Tremolada, who realised her dream to create the Ecological Park Fundo San José and open it to the public and researchers. Jonas R. Stonis and Julia Puplesyte-Chambers are indebted to señora Carmen for her friendly welcome during our studies at Fundo San José. 
Astrotischeria dondavisi Stonis \& Diškus, sp. nov.

(Figs 19-21, 25-37, 63-70)

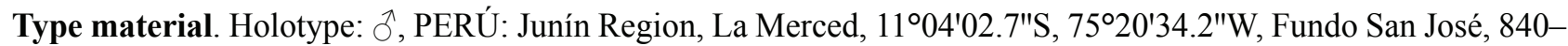
900 m, at light, 14-20.iv.2018, leg. J. R. Stonis and J. Puplesyte-Chambers, genitalia slide no. AD995 (ZMUC).

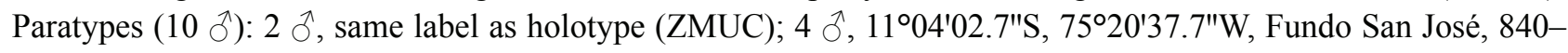
900 m, at light, 8-17.v.2018, leg. J. R. Stonis \& S. Hill (USNM); 4 §ૈ, same label as the previous, genitalia slide nos. AD994 [slide only: pinned moth used for molecular studies, not preserved], AD996 (ZMUC).
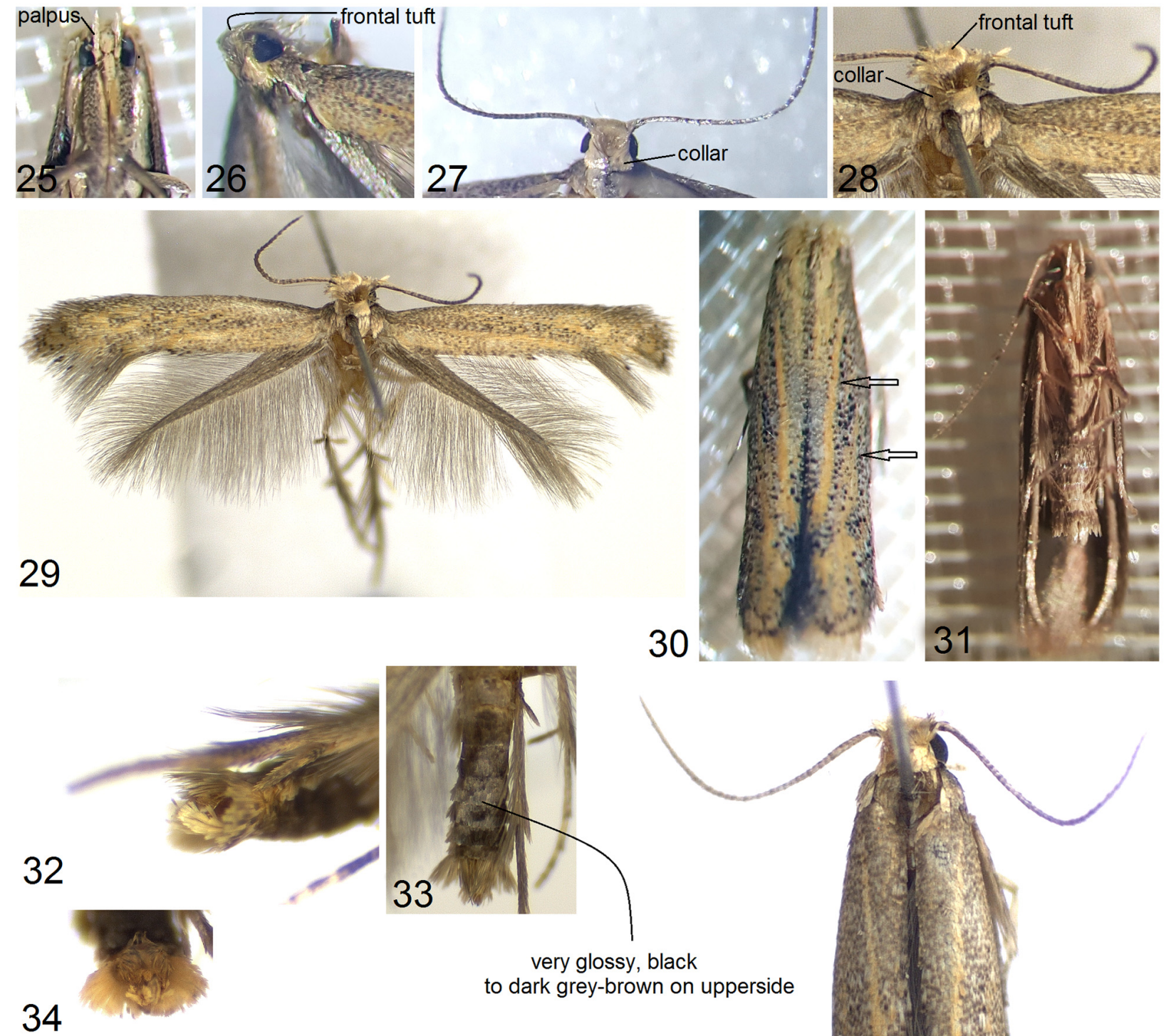

30
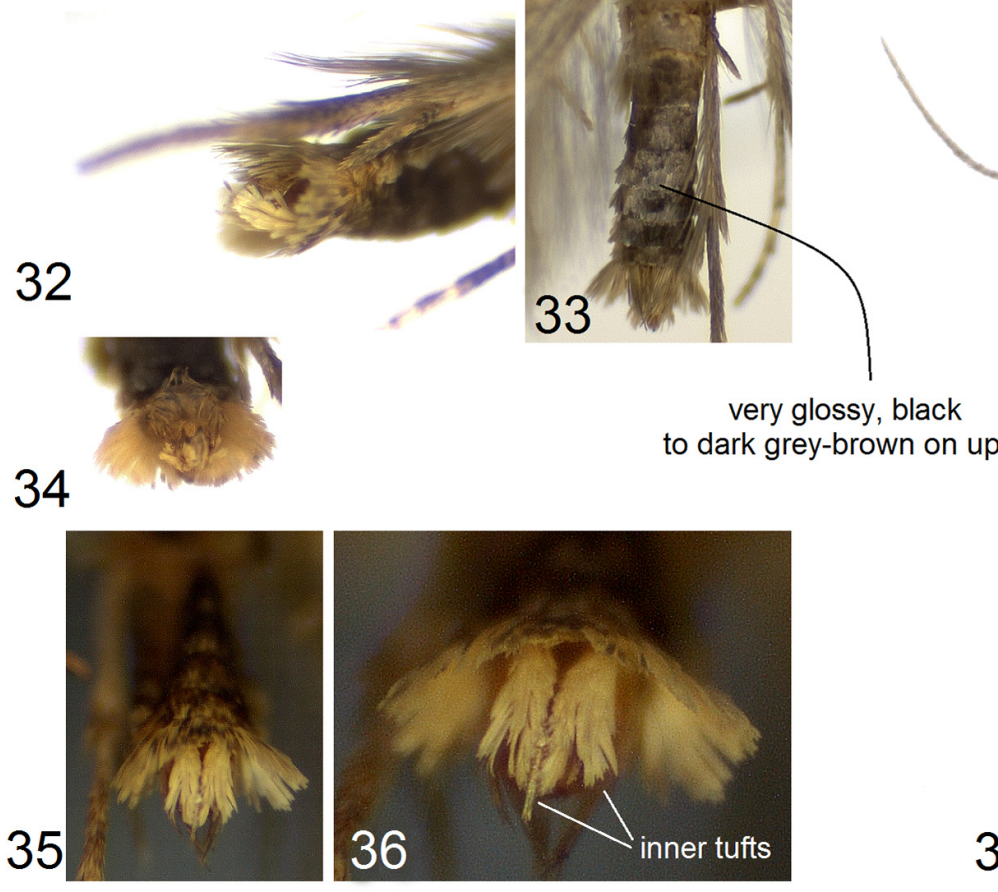

very glossy, black to dark grey-brown on upperside
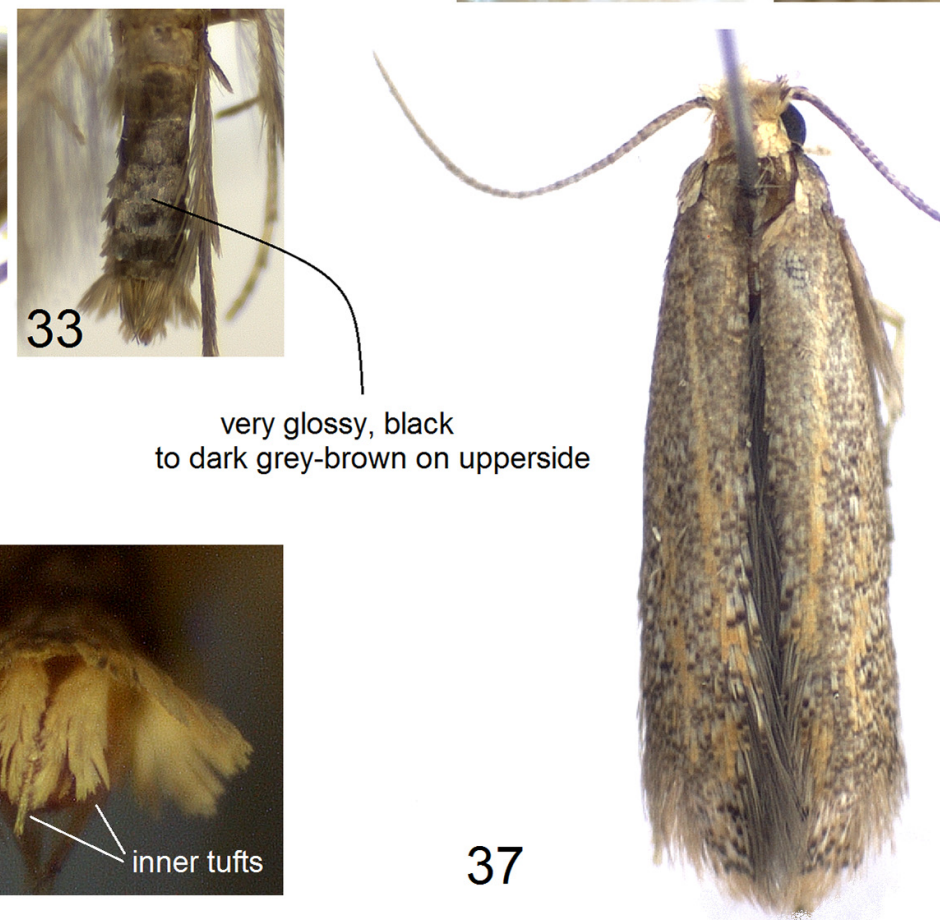

FIGURES 25-37. Male adults of Astrotischeria dondavisi Stonis \& Diškus, sp. nov. 25-28, details of head, paratype; 29, general view with abdomen removed, holotype; 30, paratype, dorsal view; 31, same, ventral view; 32-36, abdomen with anal tufts, paratypes; 37 , general view with the wings closed, paratype. 
Diagnosis. The new species belongs to the Astrotischeria trilobata group, recently revised by Stonis et al. (2018). Externally, the yellow-ochre longitudinal stripes on the forewing (Fig. 30) and large anal tufts on the abdomen (Fig. 36) make this species very distinctive. However, only male genitalia provide reliable diagnostics: the combination of a distinctly bilobed uncus (Fig. 67), very large dorsal processes of the valva, and an apically asymmetrical phallus (Fig. 66) distinguishes A. dondavisi from all known Astrotischeria species.

Description. Male (Figs 25-37). Forewing length 3.3-4.0 mm; wingspan 7.3-8.7 mm (n=9).

Head. Face triangular, smooth-scaled, golden cream to yellow-ochre, with some grey-brown scales; labial palpus golden cream, with some grey-brown scales; frontal tuft and collar yellow cream, with some grey-brown scales; antenna slightly longer than one-half length of forewing; flagellum glossy, grey-brown to yellowish grey, basally yellow-ochre with some grey-brown scales.

Thorax. Thorax, tegula, and forewing speckled with brown and black-tipped scales; sometimes black-tipped scales are not numerous; forewing usually with distinctive longitudinal, yellowish ochre stripes (Fig. 30); fringe grey; forewing underside grey-brown, without spots or androconia. Hindwing and its fringe very glossy, grey on upper side and underside, without androconia. Legs yellowish cream, densely covered with dark grey-brown scales on upper side.

Abdomen. Glossy, black to dark grey-brown with little or no purple iridescence on upper side, grey-brown on underside; anal tufts (Figs 32-36) large, six in total: two dorsal, two ventral and two inner (Figs 35, 36). Genitalia (Figs 63-70) with capsule 570-635 $\mu \mathrm{m}$ long, 330-350 $\mu \mathrm{m}$ broad. Uncus (Fig. 67) comprised of two wide dorsal lobes and two slender ventral lobes. Valva divided (Figs 63, 64, 67): ventral lobe (main body) straight and slender, about 380-405 $\mu \mathrm{m}$ long (excluding the basal process); dorsal lobe curved and pointed distally; transtilla absent; basal process of valva long (Figs 64, 67). Anellus slightly thickened, mostly membranous, with 3-4 setae laterally (Fig. 70). Phallus about $750 \mu \mathrm{m}$ long, distally deeply bifurcated, asymmetrical (Figs 65, 66), without spines.

Female. Unknown.

Bionomics. The host plant is unknown. Adults occur in April and May, and are attracted to light.

Distribution. The species is known from the single locality, La Merced, Junín Region, central Peru, at an elevation of about $900 \mathrm{~m}$, from the "selva alta" (Figs 19-21).

Etymology. The species is named after Dr. Donald R. Davis (U.S. National Museum of Natural History, Smithsonian Institution, Washington, D.C.), an inspiring colleague, and one of the greatest insect taxonomists worldwide whose research focuses on the systematics and phylogeny of the basal families of Lepidoptera, including the superfamilies Nepticuloidea, Tischerioidea, Tineoidea, and Gracillarioidea, as well as the biology of leaf-mining and cave-dwelling moths. The first three authors of this paper are deeply indebted to Don for his generous support and various collaborations during the course of our studies on Neotropical Nepticulidae, Opostegidae, and Tischeriidae.

\section{Astrotischeria bacchariphaga Diškus \& Stonis, sp. nov.}

(Figs 6-9, 38, 39, 71-79, 121-124)

Type material. Holotype: ${ }^{\lambda}$, ECUADOR: Tungurahua Province, Baños de Agua Santa, $1^{\circ} 24^{\prime} 3$ "S, $78^{\circ} 25^{\prime} 45^{\prime \prime} \mathrm{W}$, elevation 1940 m, mining larvae on Baccharis latifolia (Ruiz \& Pav.) Pers. (Asteraceae), 9.ii.2007, ex pupa iii.2007,

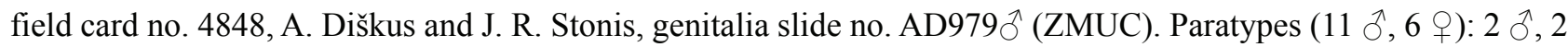
ㅇ, same label data as holotype; $6{ }^{\lambda}, 3$ ㅇ, $1^{\circ} 23^{\prime} 44^{\prime} \mathrm{S}, 7^{\circ} 26^{\prime} 14^{\prime \prime} \mathrm{W}, 9 . x i .2007$, ex pupa xii.2007, field card no. 4910,

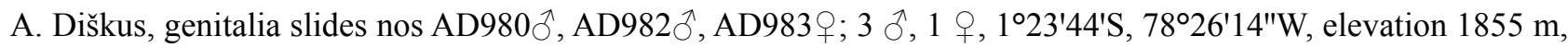
mining larvae on Baccharis emarginata (Ruiz \& Pav.) Pers. (Asteraceae), 9.xi.2007, ex pupa xii.2007, field card no.

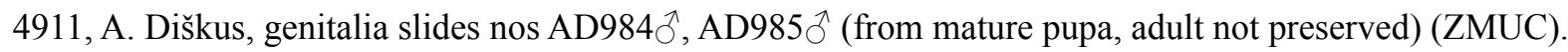

Diagnosis. Externally, this new species can be confused with some other speckled Astrotischeria species, including A. guatemalica. However, males and females of $A$. bacchariphaga possess a unique scaling of the face that is proximally grey-brown, and distally bright ochre. In the male genitalia, the combination of a distinct uncus (Figs 71, 72), large dorsal process of the valva (Fig. 71), distally thickened, round vinculum (Fig. 73), and unique phallus (Figs 74, 75) distinguishes $A$. bacchariphaga from all known congeneric species. This species is also distinctive because no other species in this genus is known to feed on Baccharis latifolia and B. emarginata.

Description. Male (Fig. 38). Forewing length 3.1-4.2 mm; wingspan 6.8-8.8 mm ( $\mathrm{n}=7)$. 

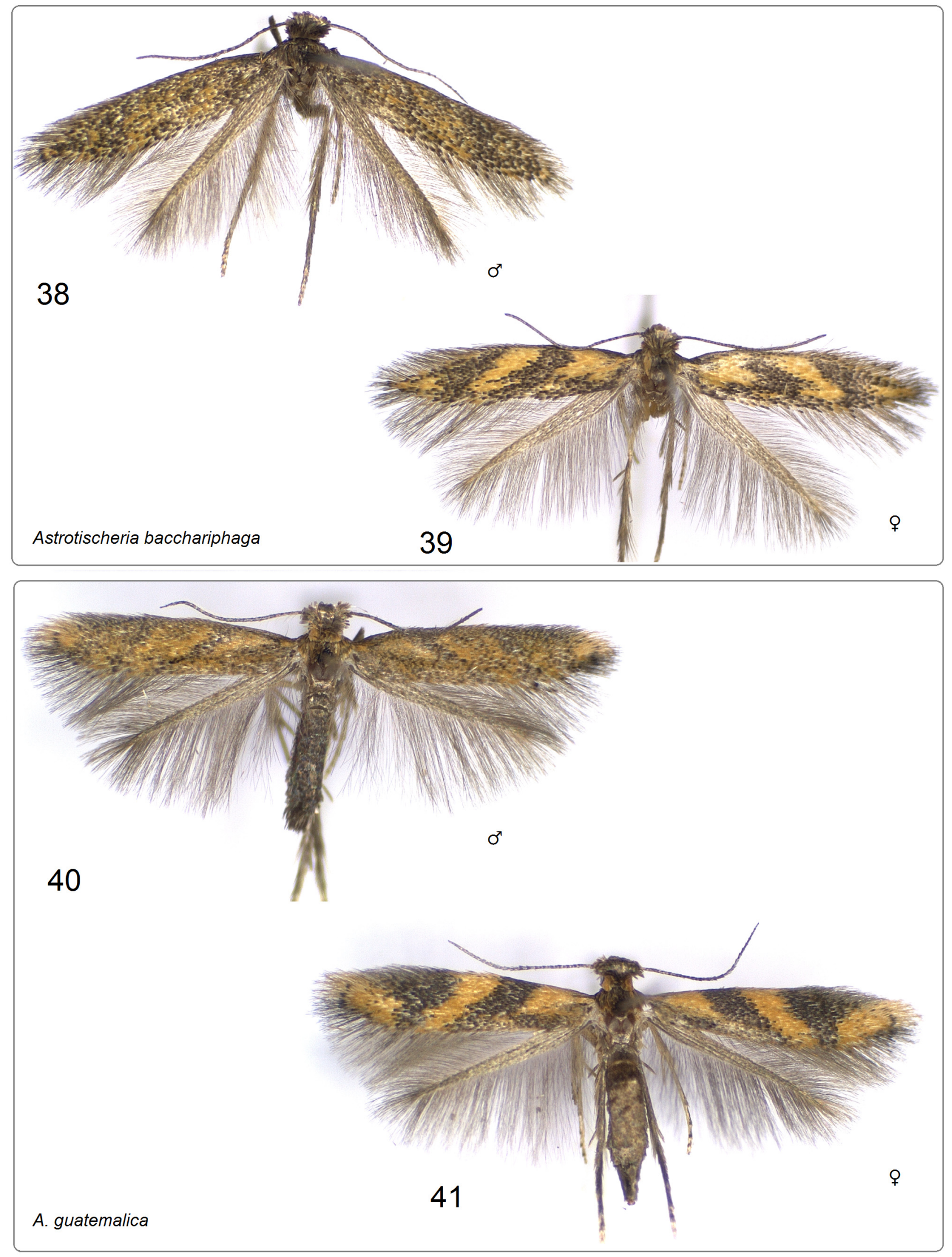

FIGURES 38-41. Male adults of new Astrotischeria species. 38, A. bacchariphaga Diškus \& Stonis, sp. nov., male, holotype; 39, same, female, paratype; 40, A. guatemalica Diškus \& Stonis, sp. nov., male, holotype; 41, same, female, paratype. 
Head. Face triangular, pale grey, distally ochre cream to bright ochre; labial palpus ochre cream, contrasting with face; frontal tuft and collar dark, grey-brown, metallic shiny at base; antenna distinctly longer than one-half length of forewing; flagellum glossy, grey-brown, irregularly annulated with darker scales.

Thorax. Tegula, thorax, and forewing covered with grey-brown scales with metallic shiny bases and irregularly speckled with ochre scales (Fig. 38); fringe pale grey-brown, with indistinct and incomplete fringe line, comprised of grey-black scales; forewing underside grey-brown, without spots or androconia. Hindwing and its fringe greybrown on upper side and underside, without androconia. Legs brownish grey.

Abdomen. Glossy, grey-brown on upper side and underside, grey cream on underside; anal tufts pale browngrey, shorter than protruding genital plates. Genitalia (Figs 71-79) with capsule 920-995 $\mu \mathrm{m}$ long, 500-550 $\mu \mathrm{m}$ broad. Uncus (Figs 71, 72, 76) comprised of two wide and very short dorsal lobes (Fig. 71) and two slender and long ventral lobes (Fig. 76). Valva (Figs 71, 72, 76) about 685-690 $\mu \mathrm{m}$ long (excluding the basal process); dorsal lobe greatly developed, very long and broad (see Fig. 71); second dorsal process of valva very small (see Fig. 79); transtilla absent; basal process of valva long (Fig. 73). Anellus only slightly thickened, mostly membranous, with 2-3 setae laterally (Fig. 73). Vinculum rounded and strongly thickened distally (Figs 73, 79). Phallus about 1090-1100 $\mu \mathrm{m}$ long, distally deeply bifurcated, symmetrical (Figs 74, 75), with two small spines on each lobe (Fig. 75).

Female (Fig. 39). Forewing length 3.3-3.8 mm; wingspan 7.2-8.2 mm ( $\mathrm{n}=8)$.

Head. Similar to male.

Thorax. Tegula and thorax covered with grey-brown scales with metallic shiny bases and irregularly speckled with ochre scales; forewing usually with three (sometimes two or one) distinctive, large, ochre patches. Otherwise as in male.

Abdomen. Glossy, pale brownish cream on upper side, yellow cream to orange-ochre on underside, without anal tufts. Genitalia (Figs 121-124) about 1995-2180 $\mu \mathrm{m}$ long. Ovipositor lobes large (Fig. 121), clothed with short, modified peg setae; area between ovipositor lobes broad, with tiny papillae and some short setae. Second pair of lobes, lateral and anterior to ovipositor lobes, much smaller than ovipositor lobes, but bearing a few very long slender setae, without stout, modified peg setae. Posterior apophyses slightly shorter than anterior ones (Figs 121, 123); prela comprised of three pairs of unique projections (Figs 121, 122). Corpus bursae long and narrow (Fig. 124), without pectinations or signum. Accessory sac inconspicuous; ductus spermathaecae very slender, with 3-4 coils.

Bionomics (Figs 6-9). The host plants are Baccharis latifolia (Ruiz \& Pav.) Pers. (Fig. 7). and Baccharis emarginata (Ruiz \& Pav.) Pers. (Asteraceae) (Fig. 6). Larvae mine leaves in February and November. Larva is brownish yellow with a pale brown head and pale green intestine. The blotch mine (Figs 8,9) is irregular, usually pale brownish, with no frass. Adults occur in March and December.

Distribution. This species is known from the single locality in Ecuador (Baños de Agua Santa), at an elevation of 1900-2000 m, but the host plants have a much broader distribution (see Discussion).

Etymology. The species name is derived from the Latin name of the host plant Baccharis in combination with the Greek phago (an eater), in reference to the feeding habit of the new species.

\section{Astrotischeria guatemalica Diškus \& Stonis, sp. nov.}

(Figs 40, 41, 80-87, 125-133)

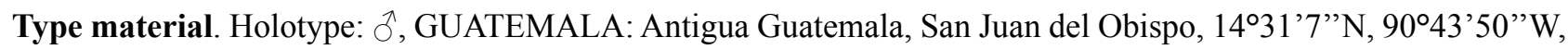
elevation $1680 \mathrm{~m}$, mining larvae 25.ii.2012, ex pupa iii.2012, field card no. 5112, A. Diškus, genitalia slide no.

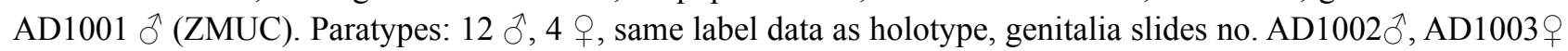
(ZMUC).

Diagnosis. Externally, this new species can be confused with some other speckled Astrotischeria species. In the male genitalia, the combination of two pairs of dorsal processes (including the slender dorsal processes, see Fig. 87), distinctive uncus (Figs 81, 83), and unique phallus (Figs 84-86) distinguishes A. guatemalica from all known congeneric species. In the female genitalia, the wide, elaborate prela (Fig. 130), the presence of a rod-like thickening (Fig. 133), and unusual shape of the corpus bursae (see Fig. 126) are hypothesized to be unique to this species. These female characters may not remain valid for species differentiation because females of many other Astrotischeria species are unknown and remain to be discovered.

Description. Male (Fig. 40). Forewing length 3.1-3.5 mm; wingspan 6.7-7.6 mm ( $\mathrm{n}=13)$.

Head. Face triangular, grey to cream grey; pecten greyish cream; labial palpus ochre cream; frontal tuft very 
glossy, black brown with purple iridescence to metallic grey, sometimes with some cream scales; collar large, ochre; antenna distinctly longer than one-half length of forewing; flagellum glossy, grey, inconspicuously annulated with ochre scales.

Thorax. Tegula and thorax covered with ochre-tipped, black scales; forewing densely speckled with ochretipped, black or black-grey scales and with a few large, but irregular ochre patches (see Fig. 40); fringe grey to dark grey, but ochre on forewing apex; fringe line indistinct and incomplete, comprised of black scales; forewing underside black-brown to black, without spots or androconia. Hindwing and its fringe grey to dark grey on upper side and underside; without androconia. Forelegs and midlegs densely covered with ochre-tipped, black-grey scales, hindlegs shiny, black-grey on upper side, glossy cream on underside.

Abdomen. With purple, green and blue iridescence; on upper side brown-black, on underside covered with brown-black scales proximally, ochre cream scales distally; anal tufts long, grey-black; genital plates grey cream. Genitalia (Figs 80-87) with capsule 935-955 $\mu \mathrm{m}$ long, 410-455 $\mu \mathrm{m}$ broad. Uncus (Figs 81, 83) comprised of two wide and very short dorsal lobes and two slender and longer ventral lobes. Valva (Figs 80, 82, 83) about 510-540 $\mu \mathrm{m}$ long (excluding the basal process); dorsal lobe greatly developed, with short, additional process (see Fig. 80); second dorsal process of valva very slender (see Figs 83, 87); transtilla absent; basal process of valva long (Fig. 87). Anellus indistinctive, mostly membranous, with $2-3$ setae laterally (Figs 80,87 ). Vinculum rounded. Phallus about $980 \mu \mathrm{m}$ long, distally with two long and two short spine-like processes (Figs 84-86).

Female (Fig. 41). Forewing length 3.4-3.8 mm; wingspan 7.4-8.1 mm $(\mathrm{n}=4)$. Similar to male, but forewing with 3 or 4 distinct, ochre patches.

Abdomen. Abdominal apex slender. Genitalia (Figs 125-133) about $2900 \mu \mathrm{m}$ long, with unique rod-like thickening (Fig. 133). Ovipositor lobes small (Fig. 129), clothed with short, modified peg setae; area between ovipositor lobes rounded and broad, with tiny papillae and some short setae. Second pair of lobes, lateral and anterior to the ovipositor lobes, much smaller than ovipositor lobes, triangular and bearing a few very long slender setae, without stout, modified peg setae. Posterior and anterior apophyses almost equal in length (Figs 125, 129); prela comprised of two pairs of unique, plate-like projections (Fig. 132) and a pair of rod-like projections. Corpus bursae long and narrow, distally oval-shaped (Fig. 126), with pectinations (see Fig. 126) and small spines (see Figs 126, 127). Accessory sac inconspicuous; ductus spermathaecae very slender with 3-4 coils and rounded vesicle (Fig. 128).

Bionomics. The host plant is unknown. Larvae mine leaves in February, producing blotch-like leaf mines. Adults occur in March. Otherwise, the biology is unknown.

Distribution. The species is known from the single locality in Guatemala (Antigua) at an elevation of about $1700 \mathrm{~m}$.

Etymology. The species is named after the country where it was collected, Guatemala.

\section{Astrotischeria sanjosei Stonis \& Diškus, sp. nov.}

(Figs 19-21, 42-46, 88-99)

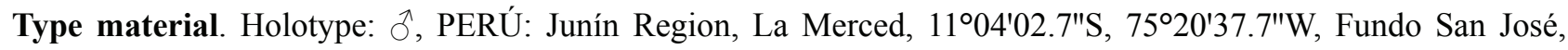
840-900 m, at light, 8-17.v.2018, leg. J. R. Stonis and S. Hill, participation by J. Puplesyte-Chambers, genitalia slide no. AD990 (ZMUC). Paratypes: 3 o (one with abdomen missing), same label as holotype, genitalia slide no. AD991 (ZMUC).

Diagnosis. Externally, this new species can be easily distinguished from all other Astrotischeria by the dark color of adults: the entire body is covered either with brown-grey or black scales, which is very unusual for the genus and uncommon for the family in general. In the male genitalia, the combination of a distinct uncus with very short dorsal lobes (Fig. 89); small, weakly developed dorsal process of valva (Figs 92, 94); long but very slender, process-like ventral plate of vinculum (Fig. 98); and apically bilobed but symmetrical phallus distinguishes $A$. sanjosei from all known congeneric species.

Description. Male (Figs 42-46). Forewing length 3.1-3.3 mm; wingspan 6.6-7.2 mm $(\mathrm{n}=4)$.

Head. Face triangular, covered with grey and some grey cream scales; labial palpus glossy, grey cream to grey; frontal tuft and collar brown-grey; antenna slightly longer than one-half length of forewing; flagellum grey.

Thorax. Tegula, thorax and forewing with very little or no purple iridescence, densely covered with browngrey to black scales; majority of scales cream-tipped (see Figs 42, 46); fringe grey to dark grey, with indistinct and incomplete fringe line, comprised of grey-black scales; forewing underside blackish grey with very little purple iri- 
descence and without spots or androconia. Hindwing and its fringe concolorous with forewing, without androconia. Legs grey to black grey, with some grey cream scales on underside and tarsi.

Abdomen. Black-grey on upper side and underside, with little purple iridescence; anal tufts (Fig. 44) large, merged dorsally, blackish grey. Genitalia (Figs 88-99) with capsule 465-485 $\mu \mathrm{m}$ long, $215-230 \mu \mathrm{m}$ broad. Uncus (Fig. 89) comprised of two wide and very short dorsal lobes and two slender and long ventral lobes. Valva (Fig. 98) about 270-290 $\mu \mathrm{m}$ long (excluding the basal process); dorsal lobe weakly developed (Figs 92, 94, 96); transtilla absent; basal process of valva long (Fig. 88). Anellus slightly thickened, mostly membranous, with 2-3 setae laterally (Fig. 96). Phallus about 470-510 $\mu \mathrm{m}$ long, distally deeply bifurcated, symmetrical (Fig. 99), with two small spines on each lobe (Fig. 95).

Female. Unknown.

Bionomics. The host plant is unknown. Adults occur in May, and are attracted to light.

Distribution. The species is known from the single locality, La Merced, Junín Region, central Peru, at an elevation of about $900 \mathrm{~m}$, from the "selva alta" (Figs 19-21).

Etymology. The species is named after a private ecological park, Fundo San José.

\section{Astrotischeria truncata Diškus \& Stonis, sp. nov.}

(Figs 10-18, 47, 48, 100-111, 134-139)

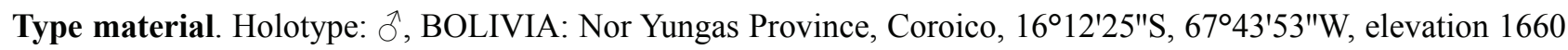
m, mining larvae on Asteraceae, 15.vi.2018, ex pupa vii.2018, field card no. 5266, A. Diškus and J. R. Stonis, geni-

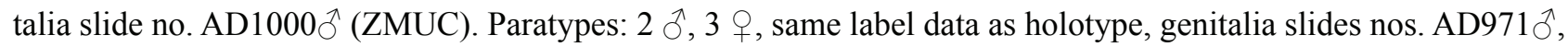
AD972 ${ }^{\wedge}$ (from an adult in pupal skin), AD974ㅇ (ZMUC).

Diagnosis. Externally the new species can be confused with some other speckled Astrotischeria species, including the Ecuadorian A. bacchariphaga and the Central American A. guatemalica. In the male genitalia, the presence of a third dorsal truncated process of the valva (Figs 105, 107) distinguishes $A$. truncata from all known congeneric species.

Description. Male (Fig. 48). Forewing length about $3.8 \mathrm{~mm}$; wingspan about $8.1 \mathrm{~mm}(\mathrm{n}=1)$.

Head. Face pale ochre to golden cream; labial palpus yellow cream; pecten ochre cream; frontal tuft and collar glossy, ochre cream to golden cream, distally with some brown-tipped scales; antenna slightly longer than one-half length of forewing; flagellum glossy, yellow-ochre proximally, greyish cream distally, irregularly annulated with dark, grey-brown scales.

Thorax. Tegula, thorax, and forewing glossy, pale ochre to yellow ochre, with some irregular patches of greybrown scales; fringe ochre on forewing apex, elsewhere grey; fringe line grey-black; forewing underside pale greybrown, except distinctly ochre at apex, without androconia. Hindwing and its fringe brownish cream to pale grey on upper side and underside, without androconia. Legs pale yellow-ochre, densely covered with grey-brown on upper side.

Abdomen. Glossy, pale yellow-ochre to ochre-brown on upper side, with many grey-brown scales on underside; anal tufts inconspicuous, ochre cream to yellow cream. Genitalia (Figs 100-111) with capsule $1100 \mu \mathrm{m}$ long, $445 \mu \mathrm{m}$ broad. Uncus (Figs 100, 101) comprised of two wide and very short dorsal lobes and two slender and long ventral lobes. Valva (Figs 100, 105, 108) about $750 \mu \mathrm{m}$ long (excluding basal process); two dorsal lobes greatly developed, third very wide but truncated (Fig. 105); transtilla absent; basal process of valva long (Fig. 106). Anellus mostly membranous, with $2-3$ setae laterally (Fig. 107). Vinculum rounded. Phallus 1005-1055 $\mu \mathrm{m}$ long, distally deeply bifurcated (Figs 103, 104, 111).

Female (Fig. 47). Forewing length 3.7-4.1 mm; wingspan 8.0-8.7 mm $(\mathrm{n}=2)$. Similar to male but often more brightly coloured.

Genitalia (Figs 134-139) about $2750 \mu \mathrm{m}$ long. Ovipositor lobes small (Fig. 136), with short, modified peg setae; area between ovipositor lobes rounded, with tiny papillae and some short setae. Second pair of lobes, lateral and anterior to ovipositor lobes, much smaller than ovipositor lobes, but bearing a few long slender setae, without stout, modified peg setae. Anterior and posterior apophyses almost equal in length (Fig. 135); prela comprised of three pairs of long and very long rod-like projections (Figs 134-136). Corpus bursae long, distally wide and rounded, with pectinations (see Fig. 137). Accessory sac inconspicuous; ductus spermathaecae very slender, with 5-6 coils and rounded vesicle (Figs 138, 139). 

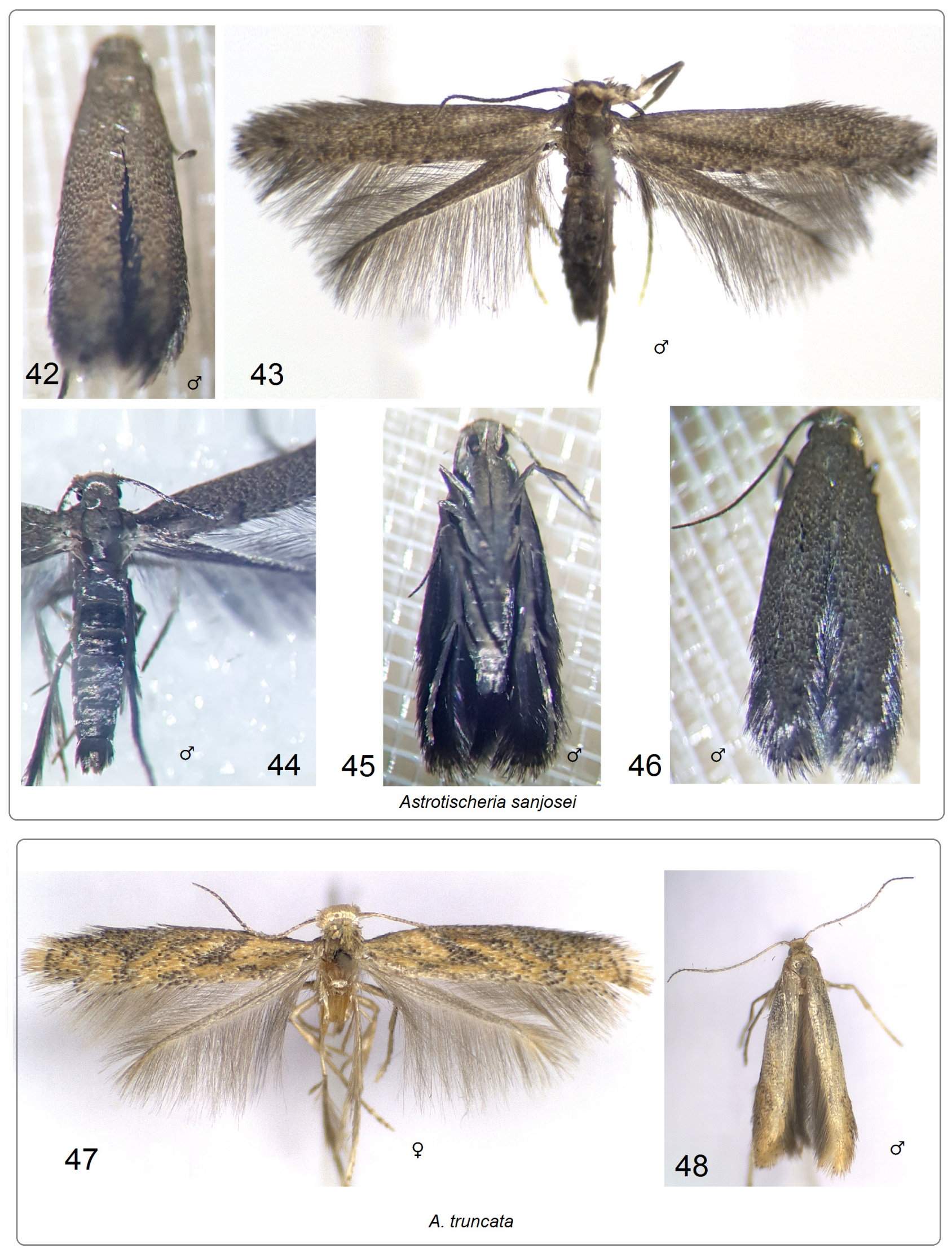

FIGURES 42-48. Adults of new Astrotischeria species. 42-46, A. sanjosei Stonis \& Diškus, sp. nov.; 47, A. truncata Diškus $\&$ Stonis, sp. nov., female, paratype; 48, same, male, holotype. 

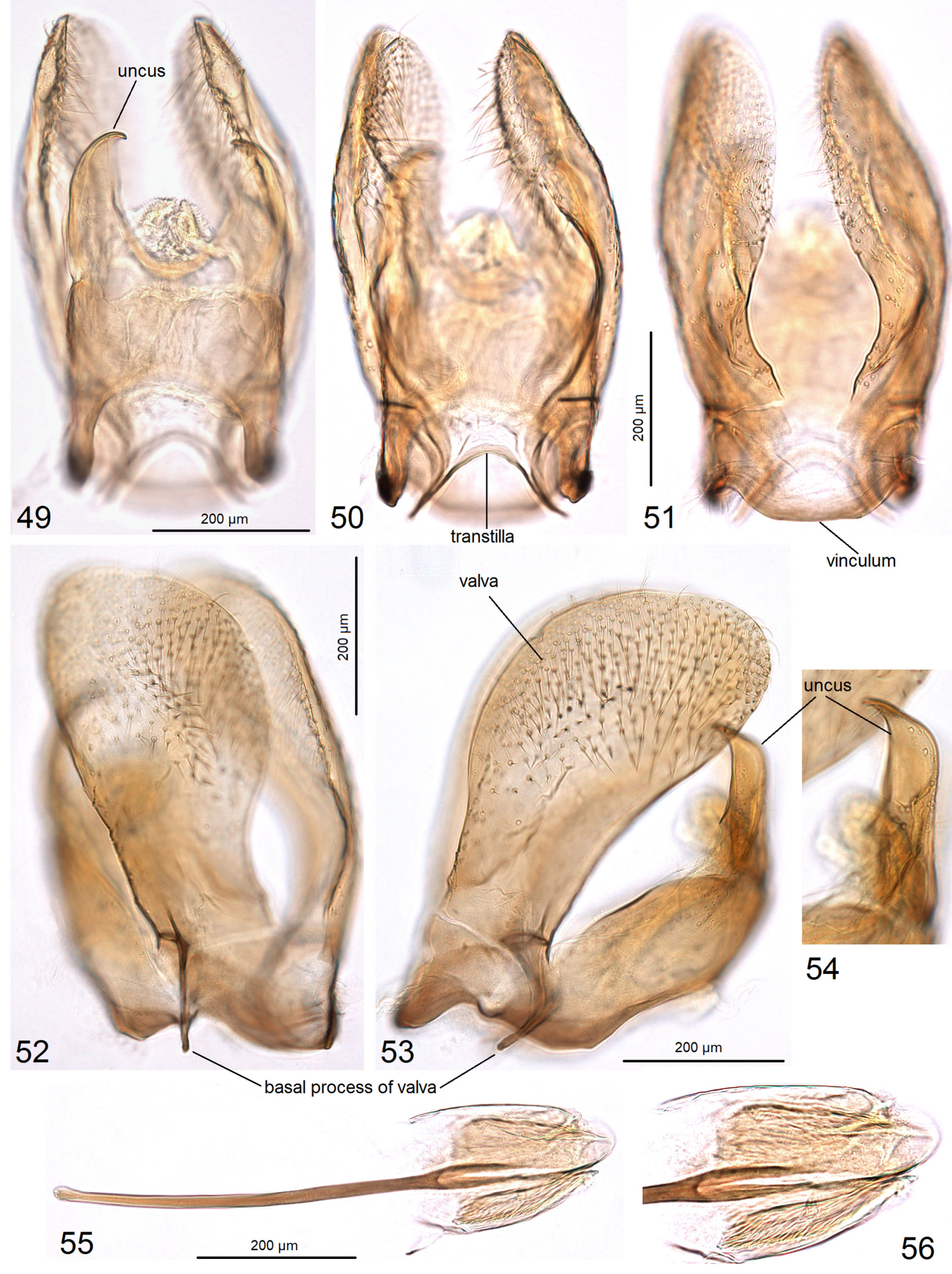

vinculum

FIGURES 49-56. Male genitalia of Coptotriche parvisacculata Diškus \& Stonis, sp. nov., paratype, genitalia slide no. AD966. 49-51, ventral view of capsule with phallus removed, focussed on uncus (49), transtilla (50), valva and vinculum (51); 52-54, lateral view with phallus removed; 55, 56, phallus. 

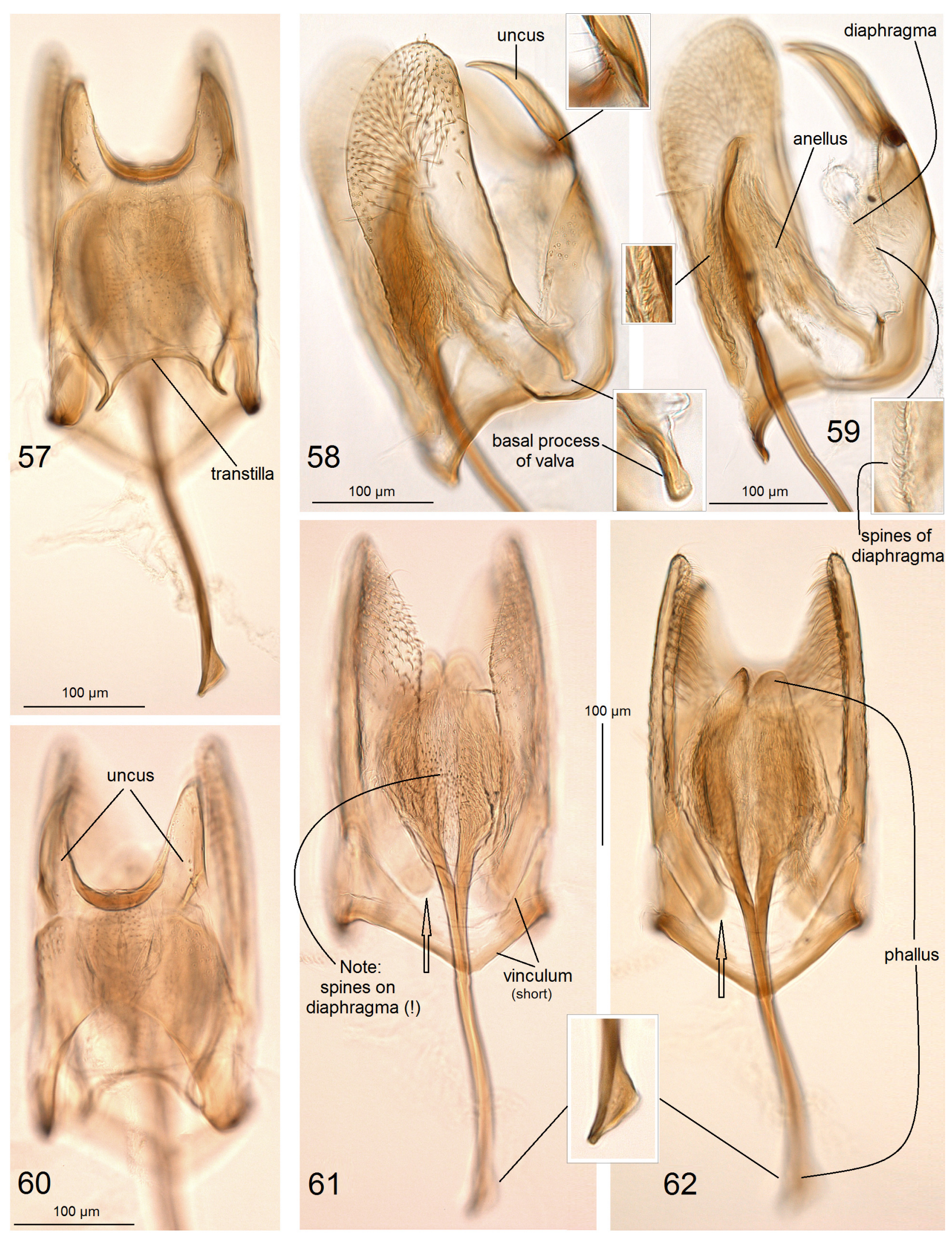

FIGURES 57-62. Male genitalia of Coptotriche carmencita Stonis \& Diškus, sp. nov., holotype, genitalia slide no. AD992. 57, dorsal view of genital capsule focussed on transtilla; 58, 59, lateral view of capsule focussed on valva and anellus; 60 , ventral view focussed on uncus and tegumen; 61, 62, ventral view focussed on phallus, valva and vinculum. 


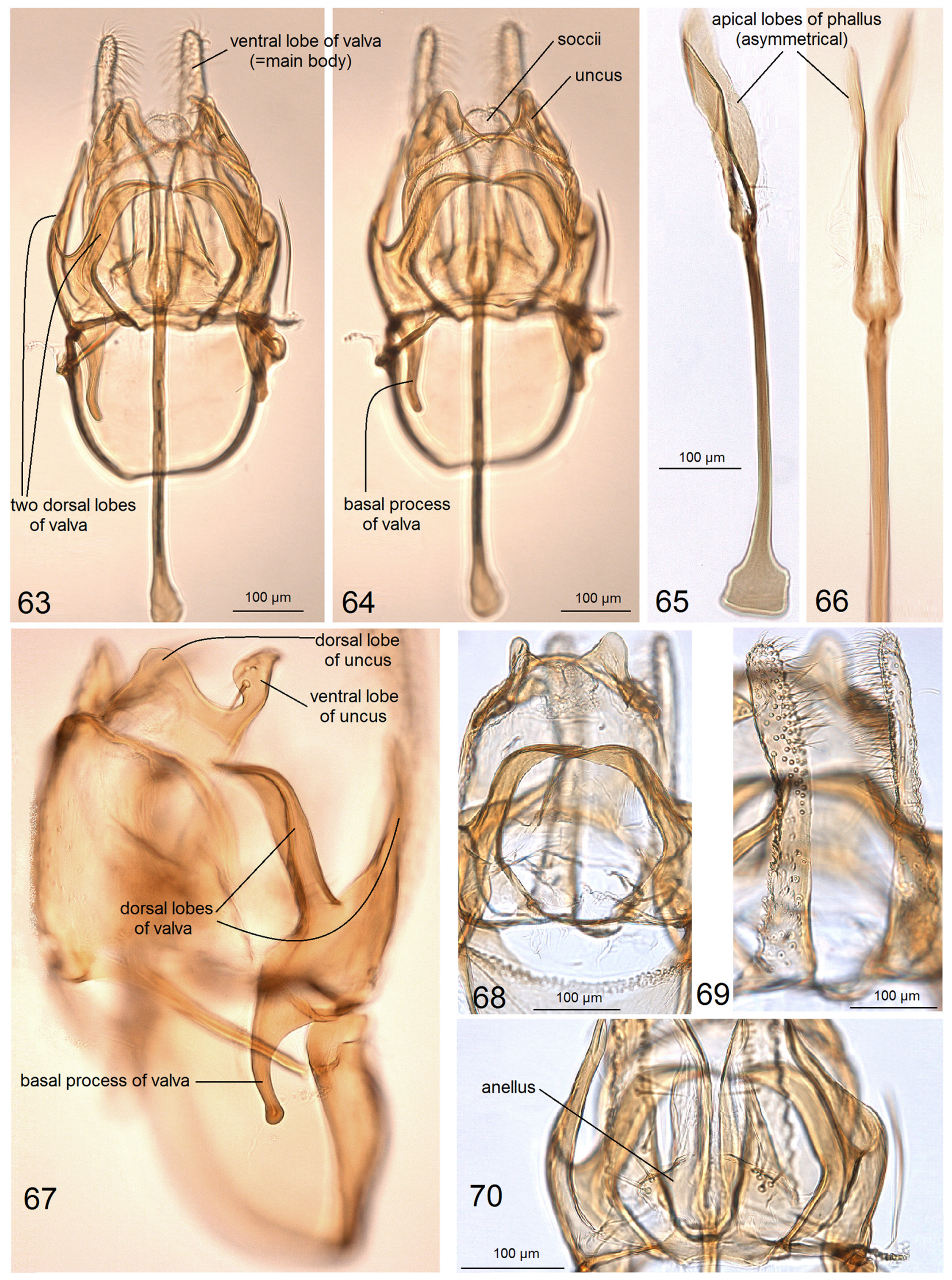

FIGURES 63-70. Male genitalia of Astrotischeria dondavisi Stonis \& Diškus, sp. nov. 63, 64, general view of capsule with phallus, holotype, genitalia slide no. AD995; 65, phallus, paratype, genitalia slide no. AD996; 66, same, paratype, genitalia slide no. AD994; 67, lateral view of capsule with phallus removed, paratype, genitalia slide no. AD994; 68-70, details of capsule, holotype, genitalia slide no. AD995. 


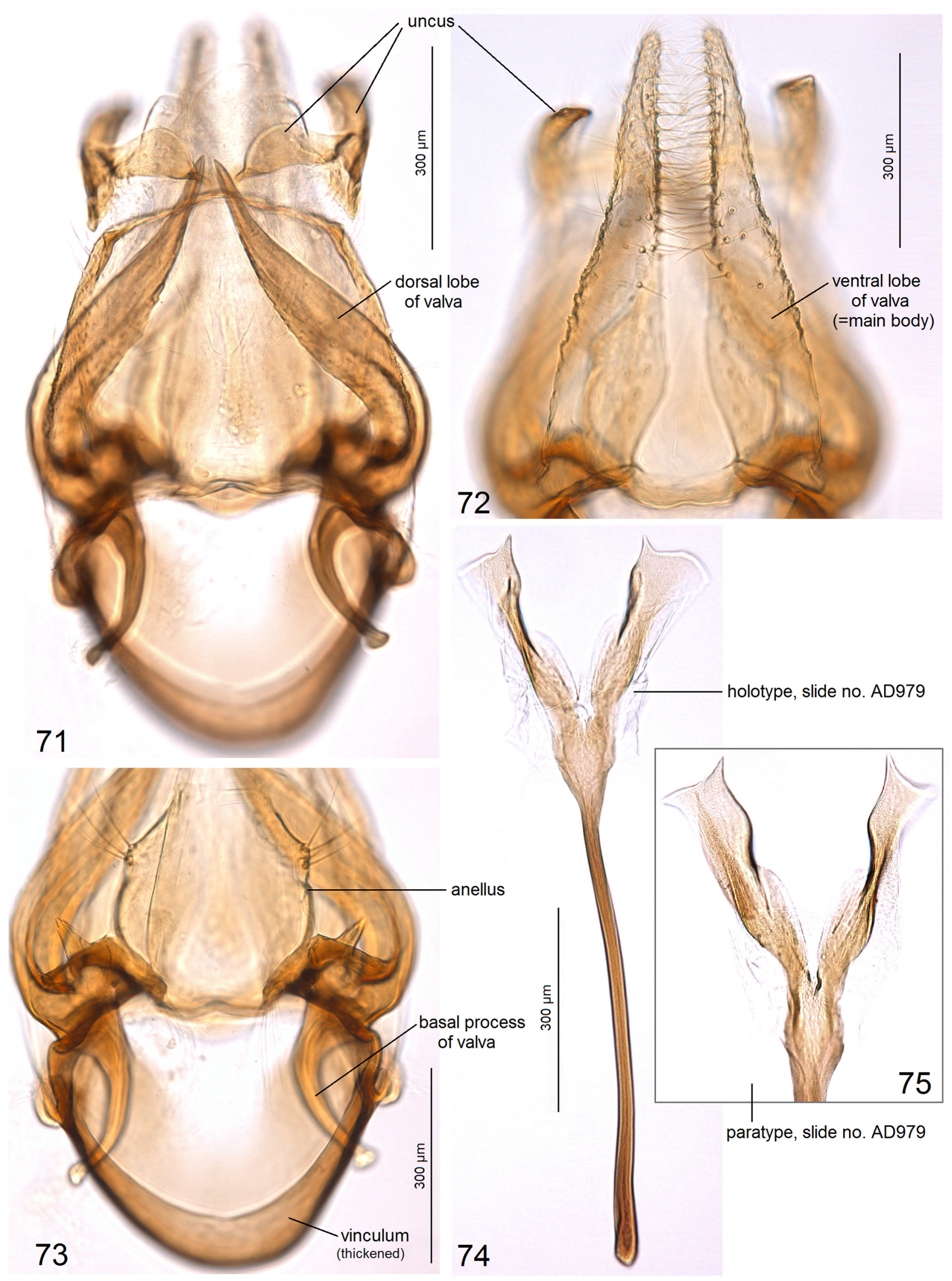

FIGURES 71-75. Male genitalia of Astrotischeria bacchariphaga Diškus \& Stonis, sp. nov. 71, holotype, genitalia slide no. AD979, capsule with phallus removed, focussed on dorsal lobes of valva; 72, same, ventral lobes of valva; 73, same, anellus; 74, same, phallus; 75, paratype, genitalia slide no. AD985. 


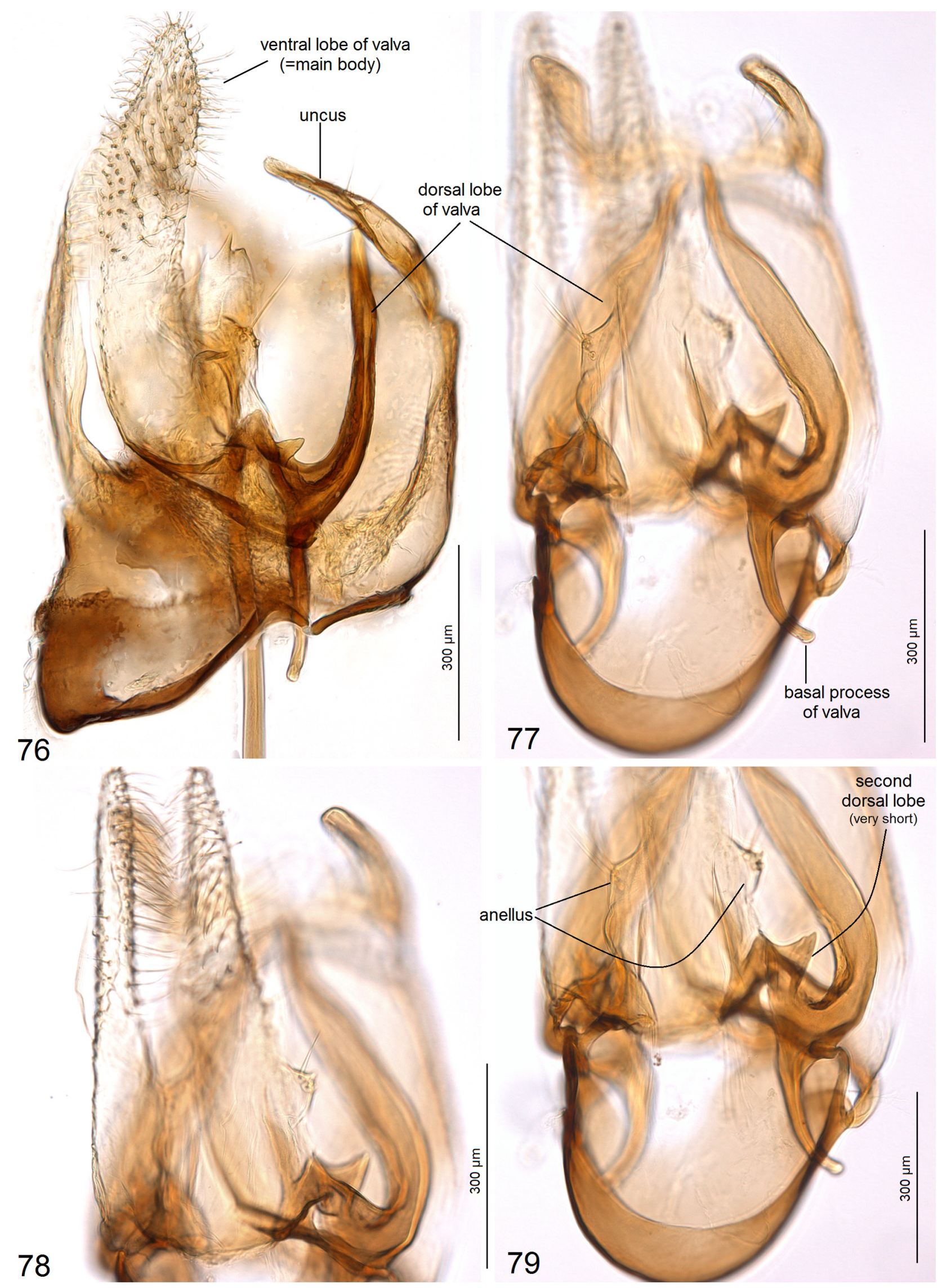

FIGURES 76-79. Details of capsule of male genitalia of Astrotischeria bacchariphaga Diškus \& Stonis, sp. nov., paratypes. 76, genitalia slide no. AD980, lateral view of capsule; 77, genitalia slide no. AD985, ventral view of capsule; 78, genitalia slide no. AD985, valvae; 79, same, anellus and dorsal lobe of valva. 


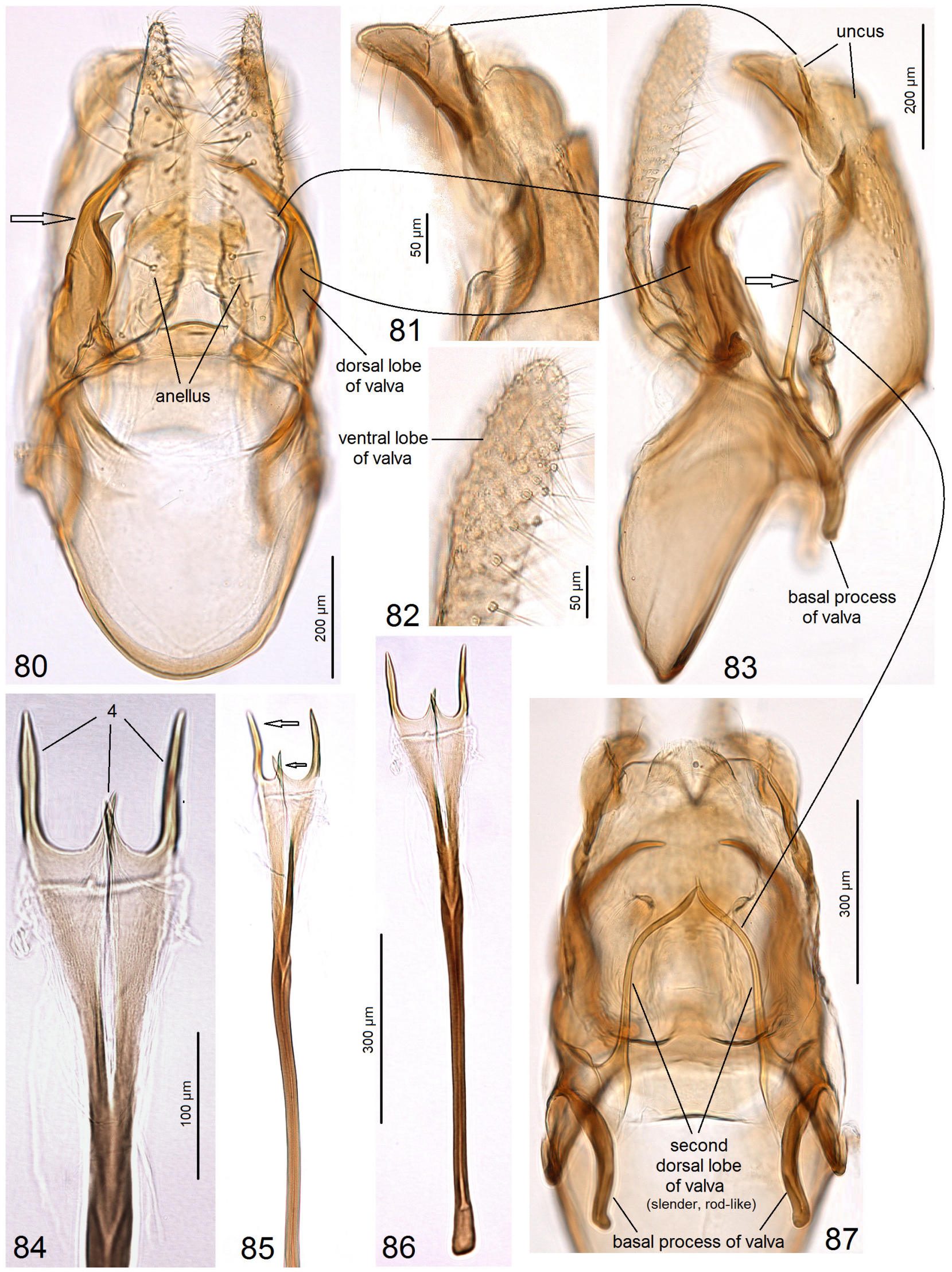

FIGURES 80-87. Male genitalia of Astrotischeria guatemalica Diškus \& Stonis, sp. nov. 80, capsule with phallus removed, holotype, genitalia slide no. AD1001; 81, uncus, lateral view, paratype, genitalia slide no. AD1002; 82, same, apex of valva; 83, same, genital capsule, lateral view; 84-86, phallus, holotype, genitalia slide no. AD1001; 87, genital capsule, focussed on dorsal lobes of valva and uncus, paratype, genitalia slide no. AD1002. 

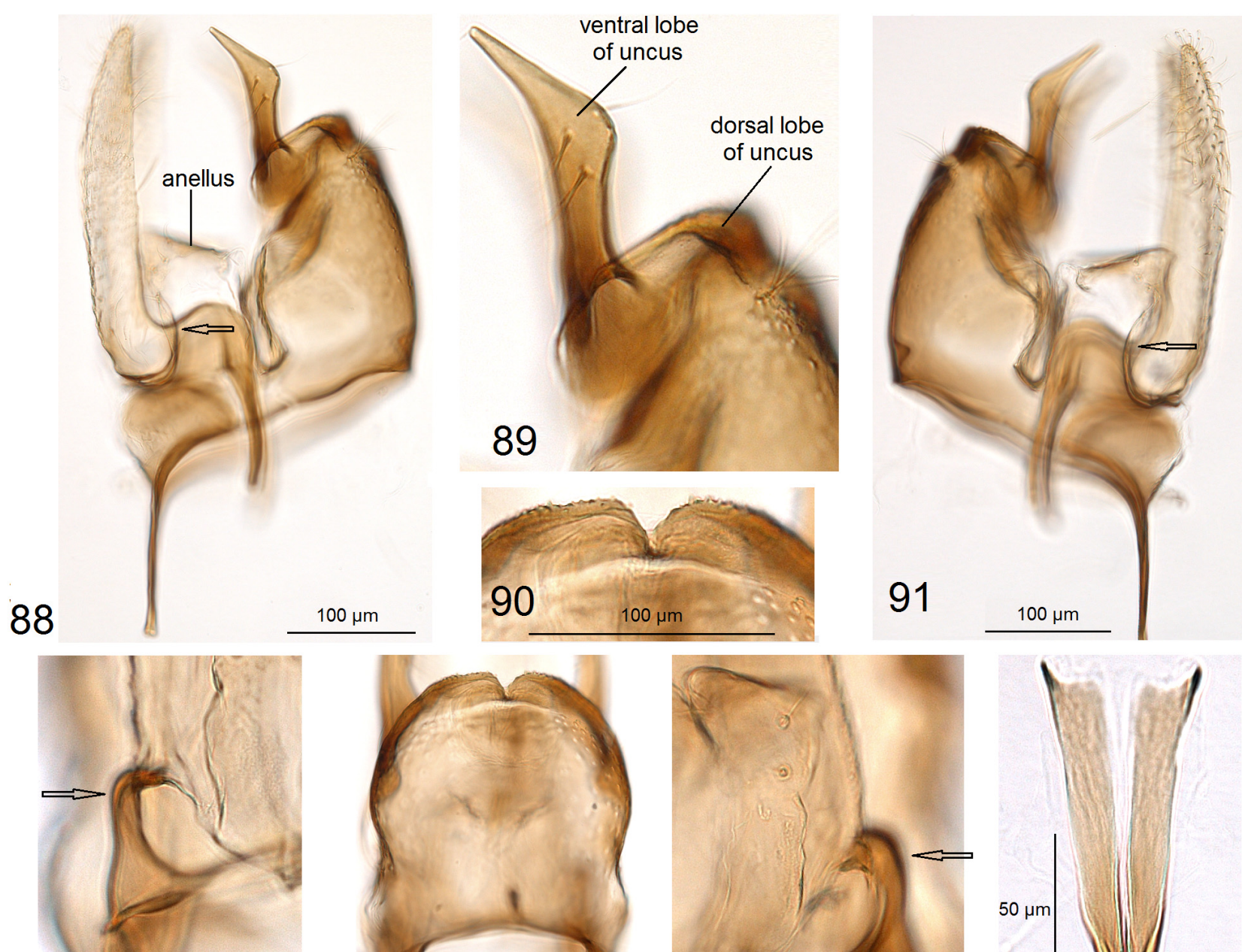

92
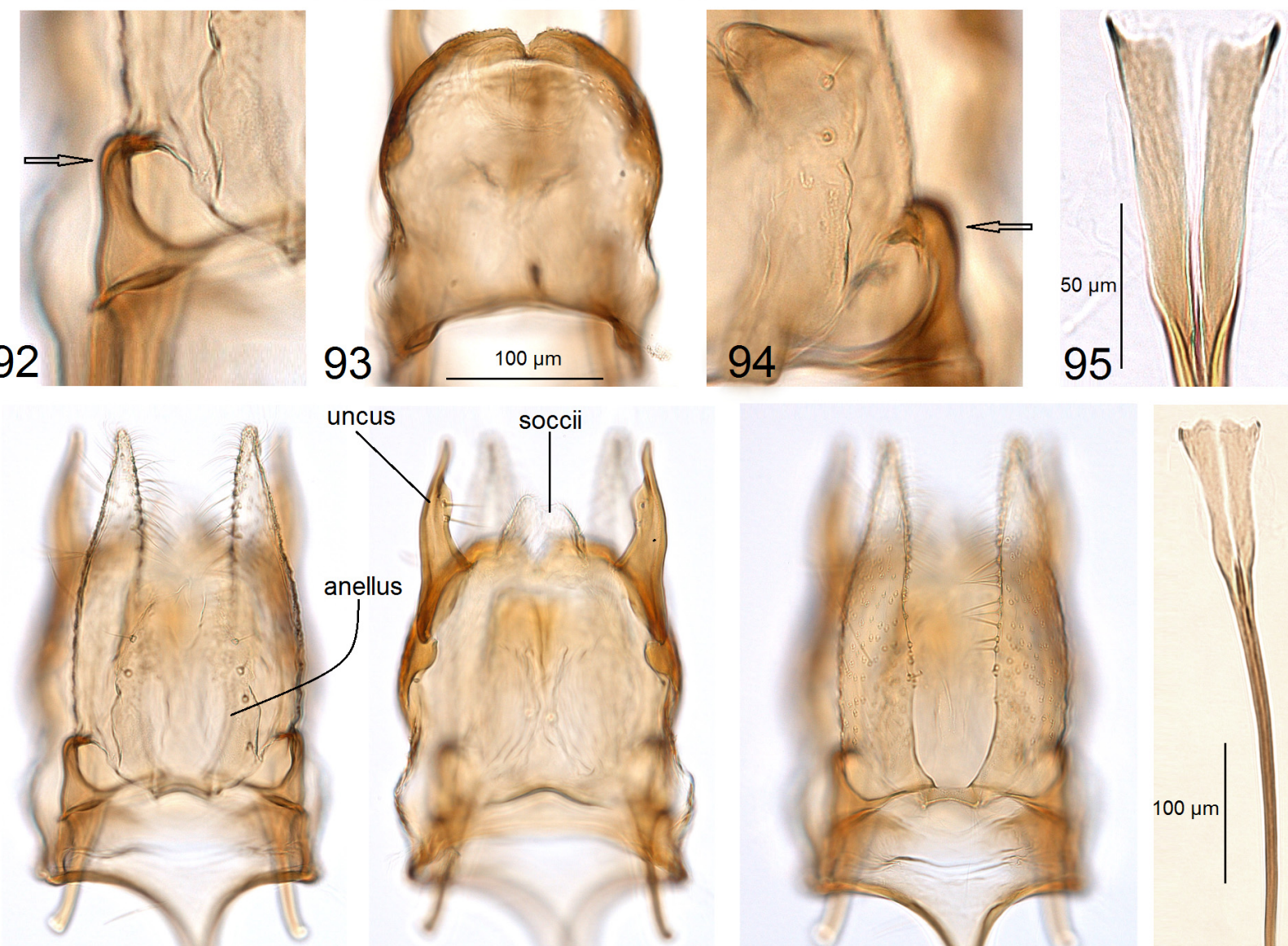

\section{6}

$100 \mu \mathrm{m}$

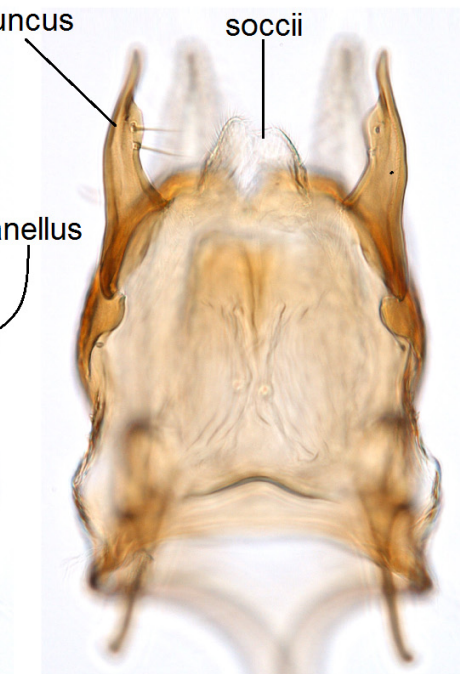

97

$100 \mu \mathrm{m}$
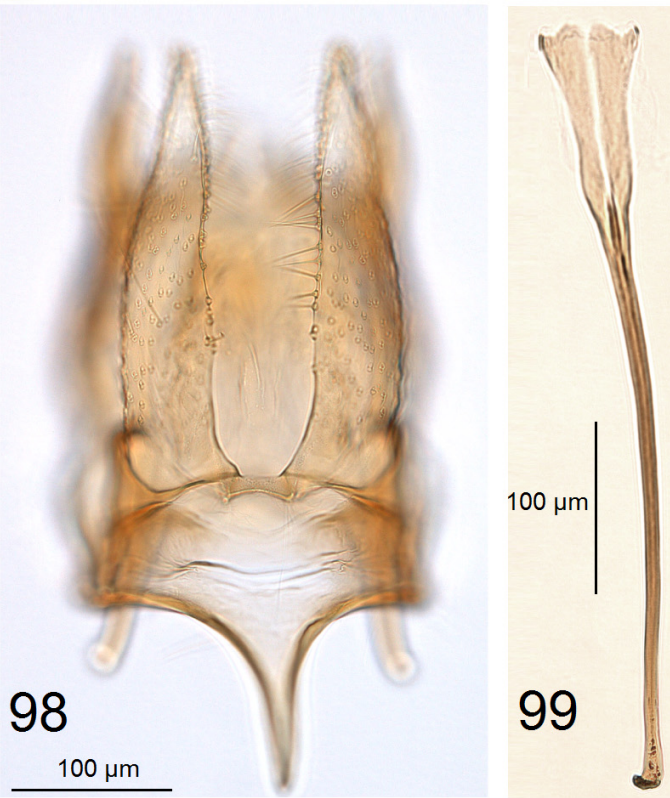

FIGURES 88-99. Male genitalia of Astrotischeria sanjosei Stonis \& Diškus, sp. nov. 88, lateral view of capsule with phallus removed, paratype, genitalia slide no. AD991; 89, same, uncus, lateral view; 90, same, dorsal lobes of uncus, dorsal view; 91, lateral view of capsule with phallus removed, paratype, genitalia slide no. AD991; 92-94, details of capsule, paratype, genitalia slide no. AD991; 95, holotype, genitalia slide AD990, apical lobes of phallus; 96-98, same, details of capsule; 99, paratype, genitalia slide no. AD991, phallus. 

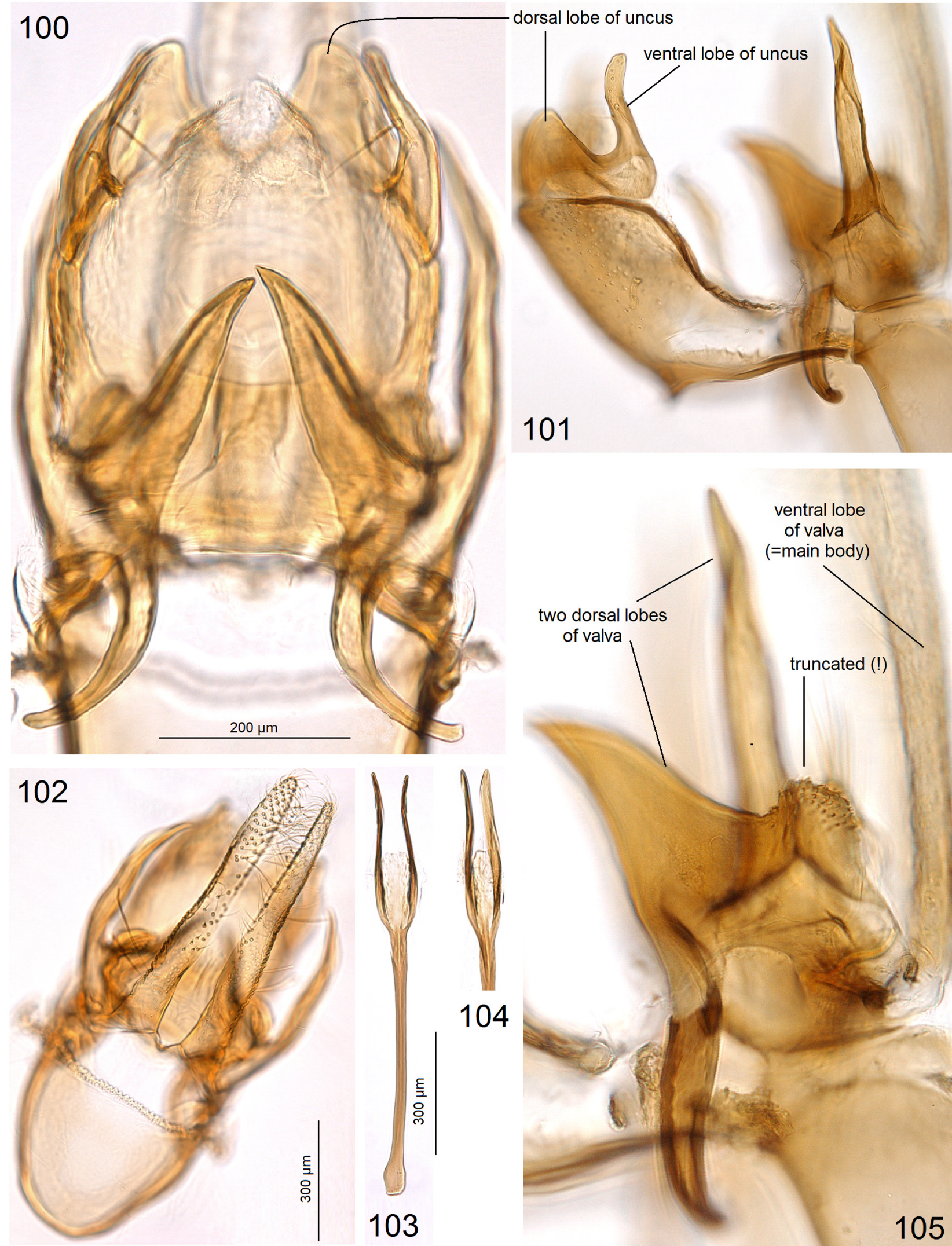

FIGURES 100-105. Male genitalia of Astrotischeria truncata Diškus \& Stonis, sp. nov. 100, capsule with phallus removed, paratype, genitalia slide no. AD972; 101, lateral view of capsule, paratype, genitalia slide no. AD971; 102, genital capsule with phallus removed, ventral view; holotype, slide no. AD1000; 103, phallus, paratype, genitalia slide no. AD972; 104, same, genitalia slide no. AD971; 105, lateral view of valva, paratype, genitalia slide no. AD971. 

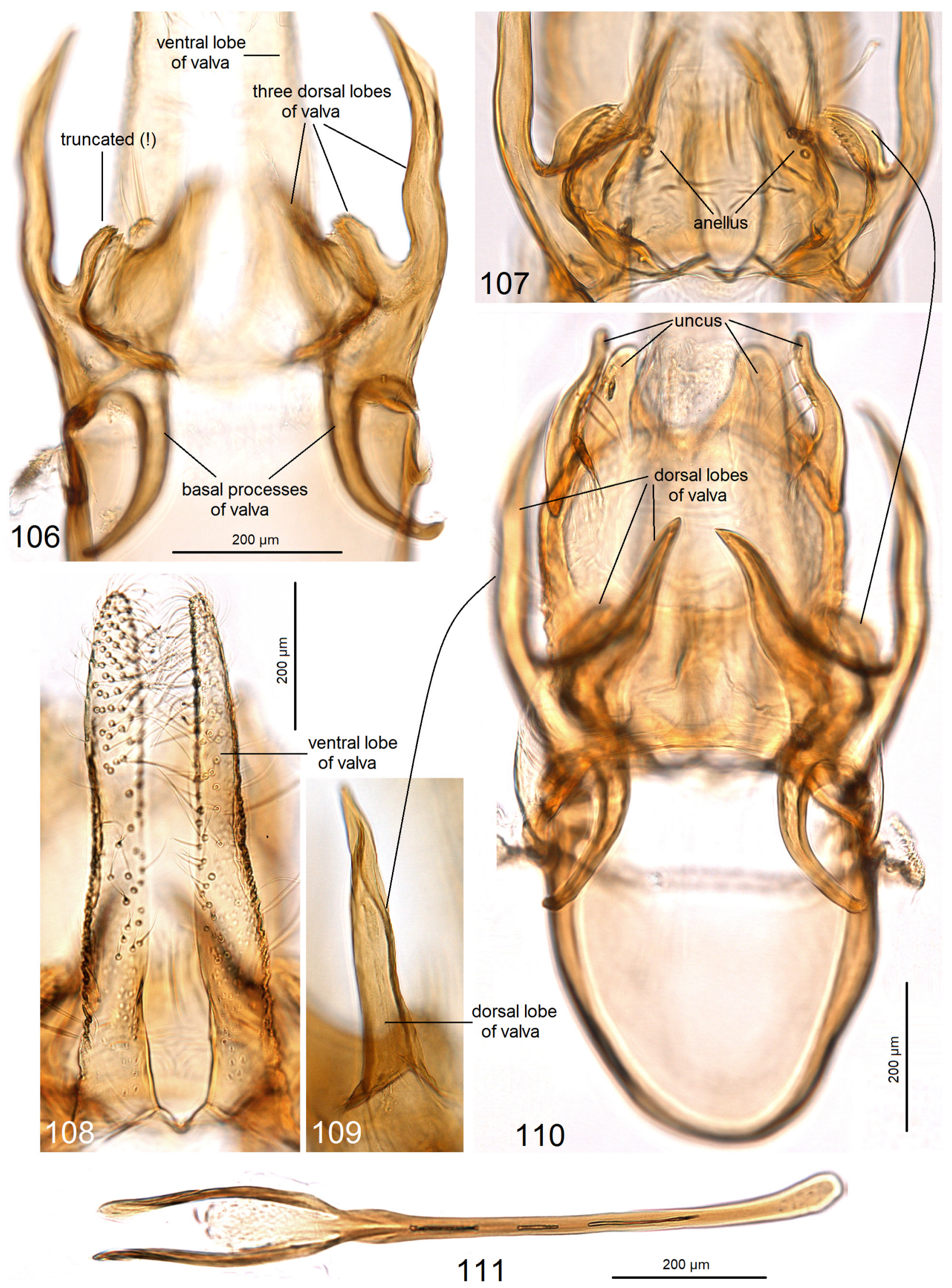

FIGURES 106-111. Details of capsule of male genitalia of Astrotischeria truncata Diškus \& Stonis, sp. nov. 106, paratype, genitalia slide no. AD971, valva; 107, holotype, genitalia slide no. AD1000, anellus and dorsal lobes of valva; 108, same, ventral lobes of valva; 109, same, dorsal lobe of valva; 110, same, general view of genital capsule with phallus removed, focussed on uncus and dorsal lobes of valva; 111, same, phallus. 

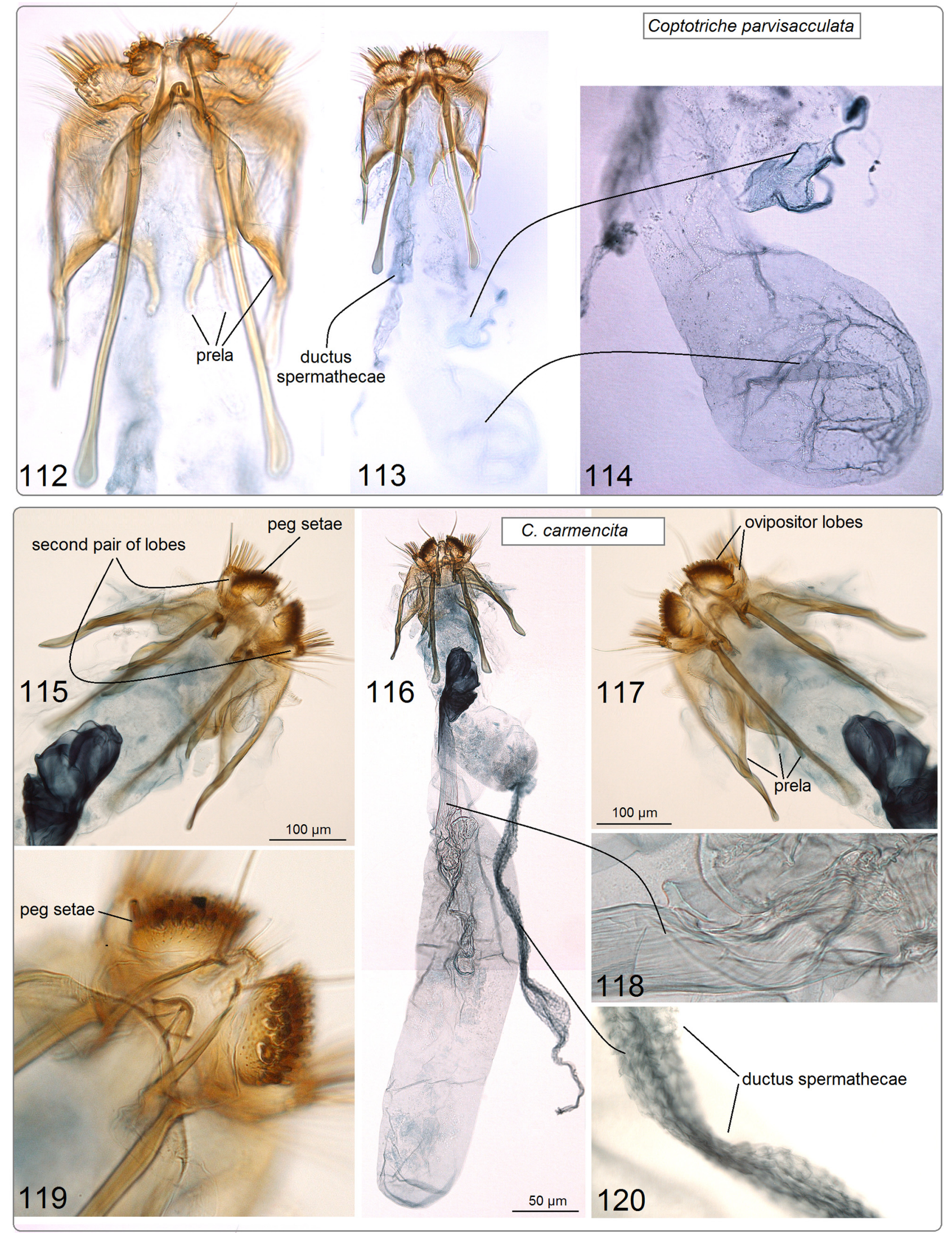

FIGURES 112-120. Female genitalia of new Coptotriche species. 112-114, C. parvisacculata Diškus \& Stonis, sp. nov., paratype, genitalia slide no. AD965; 115-120, C. carmencita Stonis \& Diškus, sp. nov., paratype, genitalia slide no. AD993. 


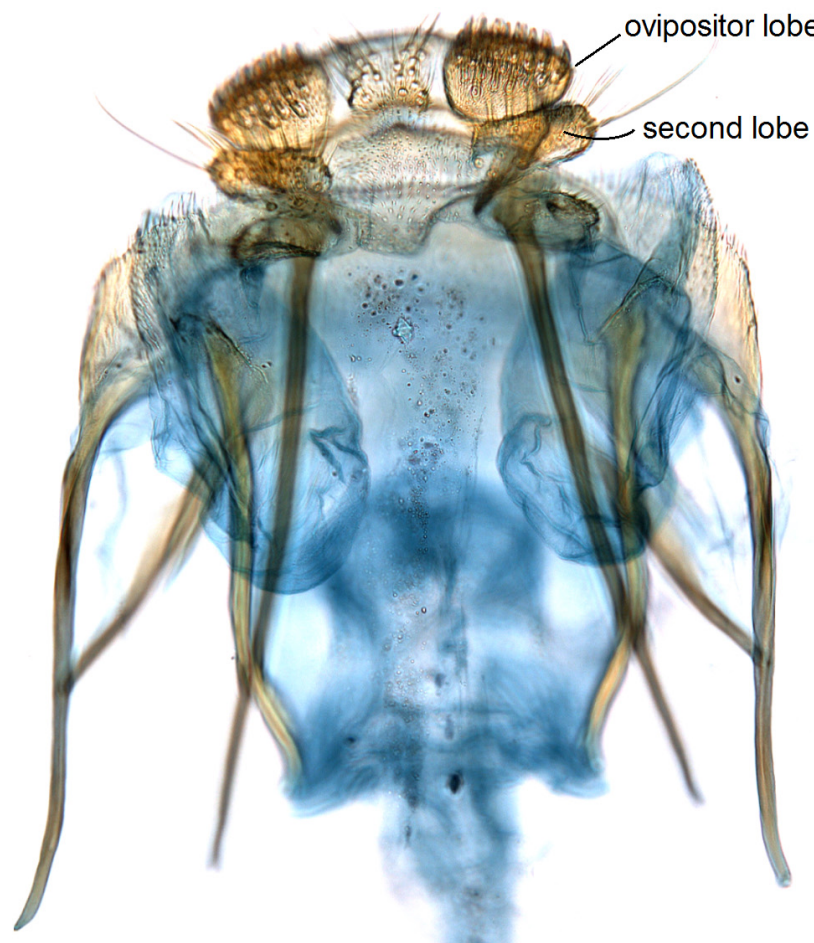

121
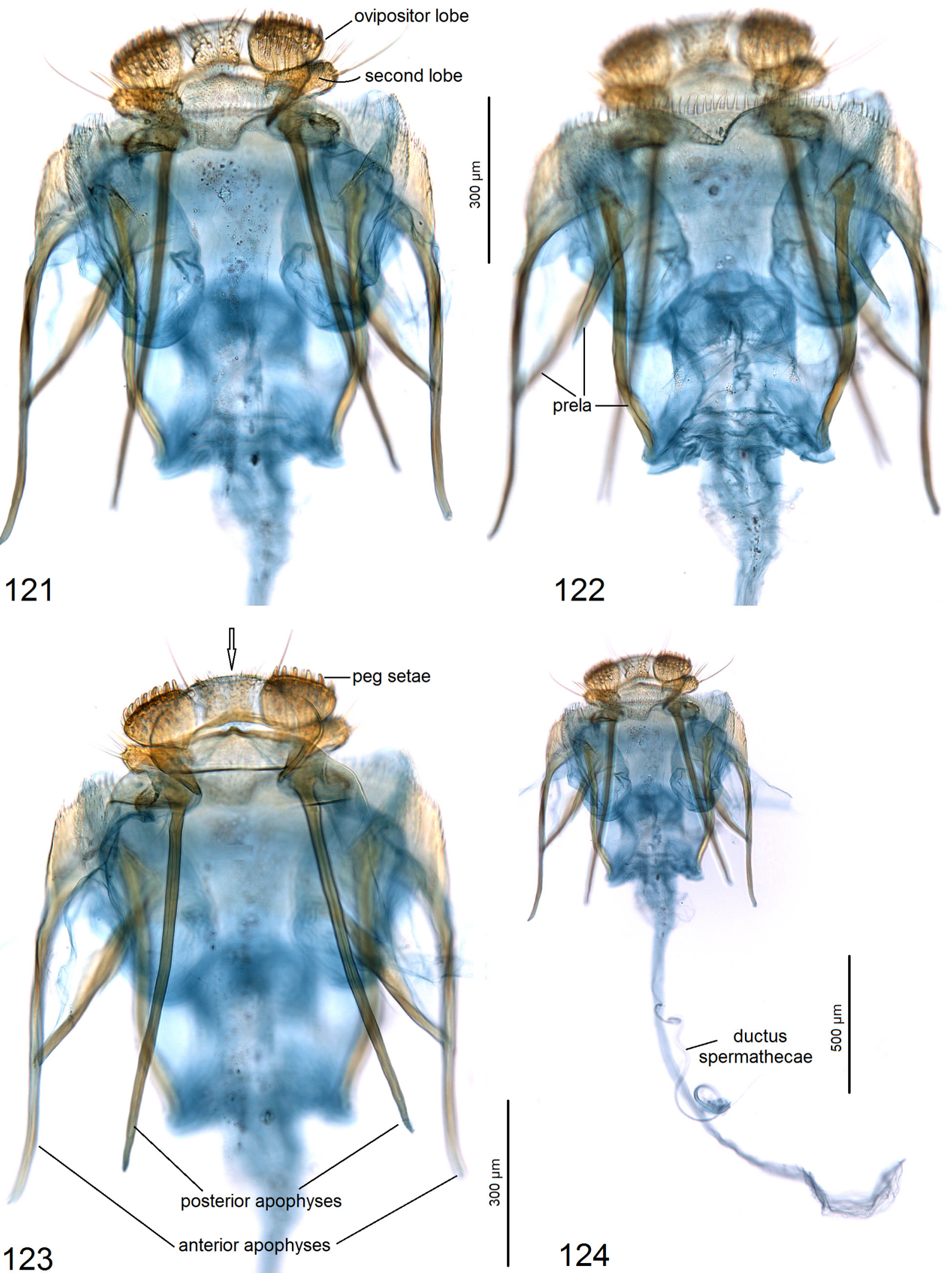

FIGURES 121-124. Female genitalia of Astrotischeria bacchariphaga Diškus \& Stonis, sp. nov., paratype, genitalia slide no. AD983. 

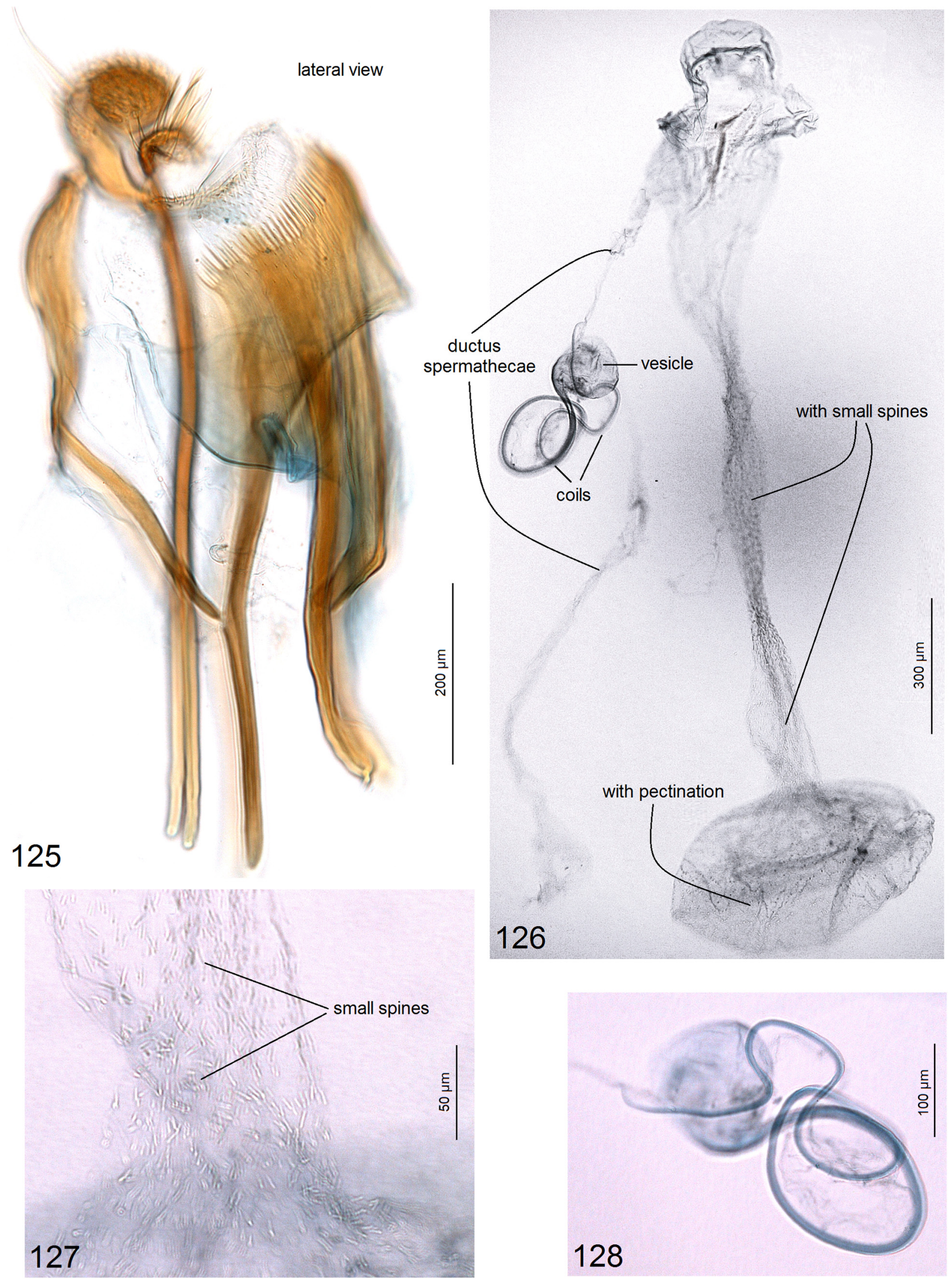

FIGURES 125-128. Female genitalia of Astrotischeria guatemalica Diškus \& Stonis, sp. nov., paratype, genitalia slide no. AD1003. 

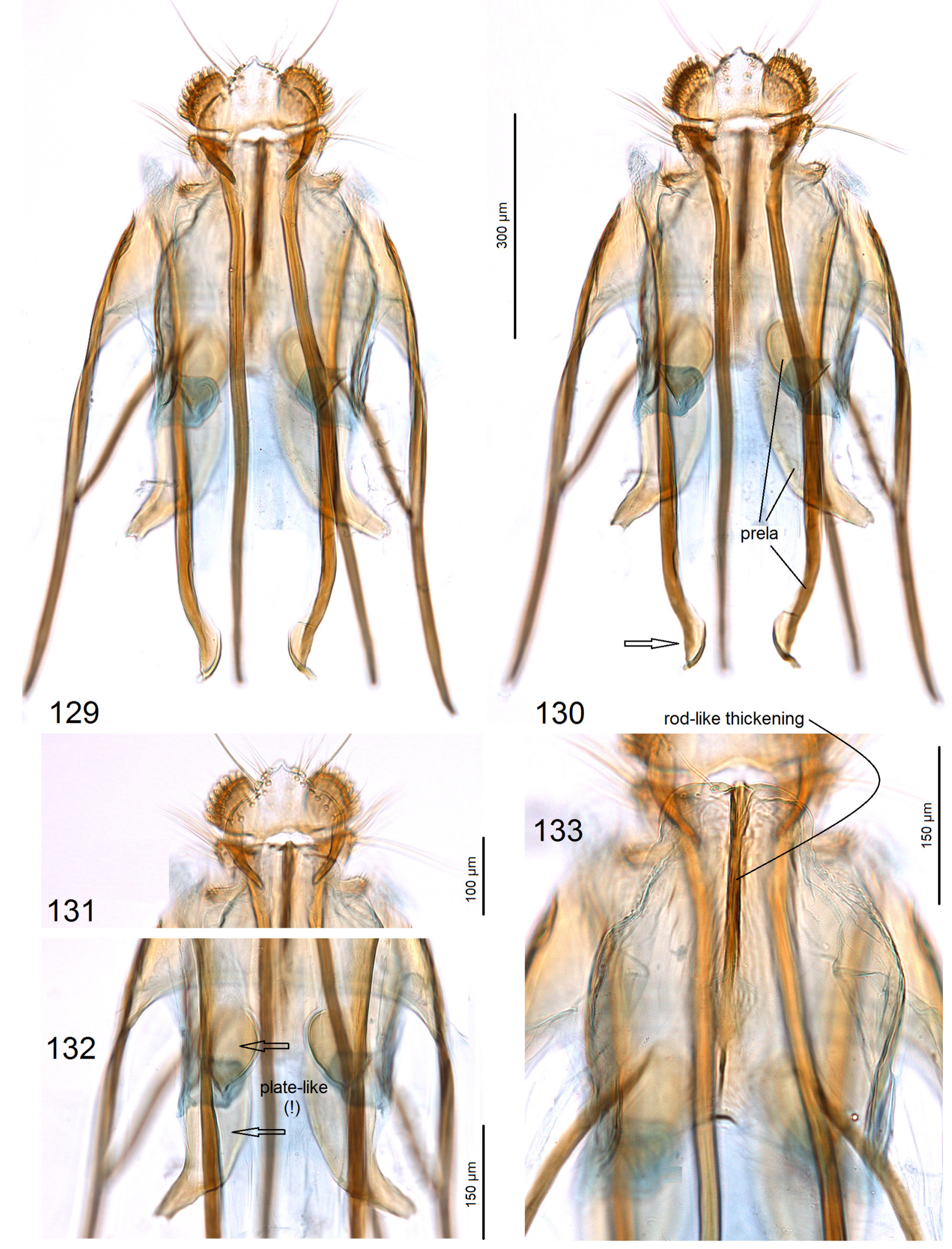

FIGURES 129-133. Female genitalia of Astrotischeria guatemalica Diškus \& Stonis, sp. nov., ovipositor and apophyses, paratype, genitalia slide no. AD1003. 


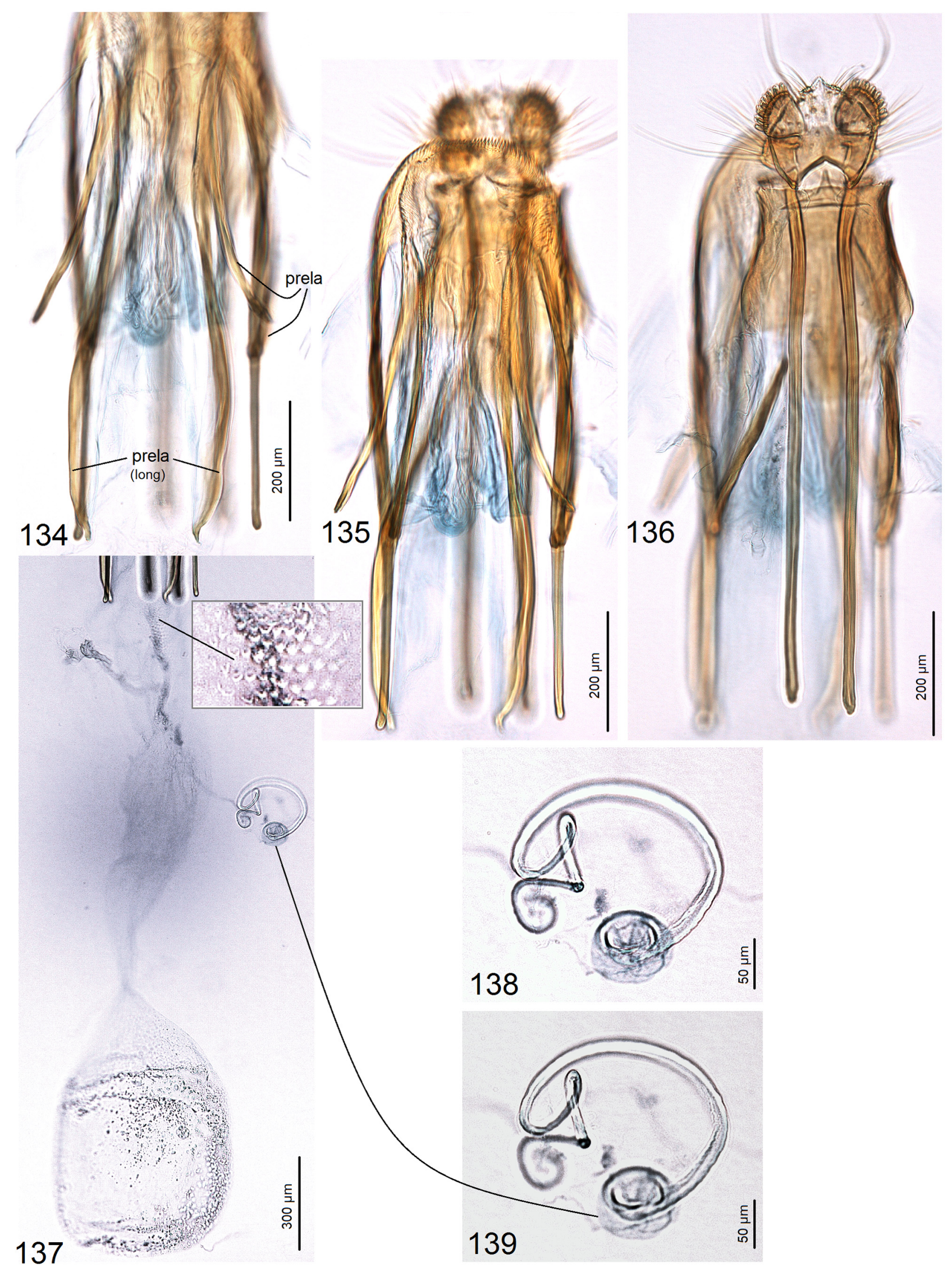

FIGURES 134-139. Female genitalia of Astrotischeria truncata Diškus \& Stonis, sp. nov., paratype, genitalia slide no. AD974. 
Bionomics (Figs 10-18). The host plant is possibly Eupatorium sp. (Asteraceae) (see Remarks) (Fig. 11). Larvae mine leaves in June. Larva is pale yellow with a pale brown head and green intestine. The blotch mine (Figs 12-18) is unusually large and long, whitish or pale brown (old mines turn brown), with no or very little frass; fully developed mines bend (distort) the mined leaf (Figs 14-18). Adults occur in July.

Distribution. The species is known only from the single locality in Bolivia (Nor Yungas Province: Coroico) at an elevation of about $1700 \mathrm{~m}$ (Fig. 10).

Etymology. The species name is derived from the Latin truncatus (trimmed, truncated) in reference to the truncated process of valva in the male genitalia.

Remarks. We thought the host plant could be a species of Eupatorium L. (det. N. Cumbicus Torres), but it (Fig. 11) remains unidentified. According to L. Katinas, it is similar to but does not exactly match Clibadium F.Allam. ex L. or Gyptis (Cass.) Cass. (both Asteraceae).

\section{Discussion}

Coptotriche in the Neotropics. The American Coptotriche Walsingham, including the Neotropical representatives, were reviewed by Stonis \& Diškus (2008). However, prior to our study there were no known Coptotriche from South America. The recent discovery of Coptotriche carmencita from Peru and C. parvisacculata from Argentina provides the first published records of the genus in South America, and based on the geographical distance between the records, it suggests that the genus might be more widespread on the continent. With respect to the morphology of the newly discovered South American species, they possess only inconspicuous, weakly developed spines on the phallus, especially in C. carmencita; most Holarctic, and particularly Palearctic species, have well developed spines on a distinctly tulip-shaped phallus (note that the spines of the phallus are among the major apomorphies of Coptotriche).

First discovery of Tischeriidae in the Peruvian "selva alta". Thanks to Julia Puplesyte-Chambers (NGO DAR Peru), who participated in the fieldwork in Chanchamayo, Peru, in cooperation with the Baltic-American Biotaxonomy Institute, we conducted the first study of the Peruvian "selva alta" (selva central). Our discovery of three new, distinctive Astrotischeria and Coptotriche species provides the first evidence of the presence of Tischeriidae in this region (Figs 19-21) that seems to be a transitional corridor between the montane regions and tropical lowlands, or the Amazonian selva ("selva baja"). It is interesting to note that the newly discovered Astrotischeria species (A. dondavisi and A. sanjosei) represent two morphological extremes of Astrotischeria, a genus which is characterized by two major apomorphies: presence of a dorsal valval lobe(s) and development of an elaborate uncus with ventral lobes. In the case of $A$. dondavisi, instead of one dorsal valval lobe, there are two highly developed dorsal lobes, and, together with the highly specialized uncus, testify to a derived morphology. Another Astrotischeria species discovered in "selva alta", $A$. sanjosei, exhibits the opposite case of male genitalic morphology. In contrast to $A$. dondavisi, $A$. sanjosei posseses only one weakly developed, rather inconspicious, dorsal valval lobe. We speculate that it represents a plesiomorphic state of the character in Astrotischeria. We surmise that recent discoveries in Peru indicate a greater taxonomic diversity of tischeriids in the "selva alta" than previously believed. However, no biological data, including host plants, are known. More focused collecting of Tischeriidae in Peru would be highly desirable in the near future.

In 2018, we were fortunate to conduct research at Fundo San José, Peru (Figs 20, 21), and found that it harbours an amazing biodiversity, including tiny, hitherto unknown, trumpet moths. We also found the Ecological Park Fundo San José to be one of the most convenient plots to study the leaf-mining fauna of the "selva alta". Fundo San José is a 43-hectare, large ecological park with the purpose of protecting the biodiversity of the Peruvian "selva alta" (central selva) and making it accessible for tourists, nature lovers, and researchers (Figs 19-21). For an intriguing prehistory about Fundo San José, see the website (Fundo San José 2019), which takes us to back to the end of nineteenth century when, after a long journey and crossing the Central Andes, Italian immigrants arrived at the region. In 2005-2006, Carmen Brocq Tremolada, of Italian ancestory, conceived an idea to share the beauty of the place and establish a lodge. Starting in 2011, with help from a multidisciplinary team of various professionals, financial contributions, and the unconditional work of the adminstrator, Lorena Brocq Tremolada, the lodge and ecological park was opened for visitors in its present scale (Fundo San José 2019). 

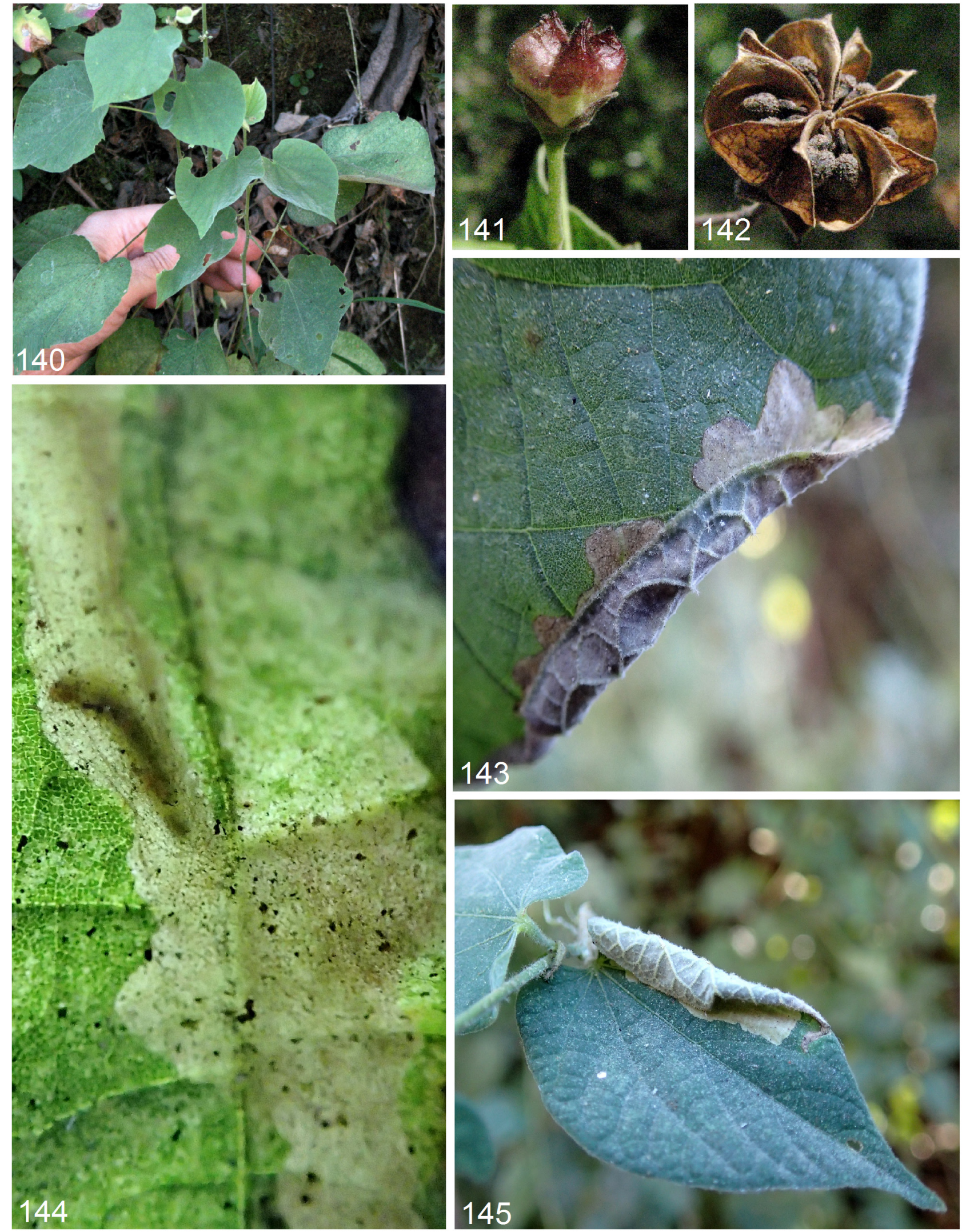

FIGURES 140-145. Bionomics of Astrotischeria ochrimaculosa Diškus, Stonis \& Vargas, 2019. 140-142, host plant, Wissadula Medik., possibly W. amplissima (L.) R.E. Fr.or W. excelsior (Cav.) C. Presl., Malvaceae (see Discussion); 143-145, leaf mines (Stonis et al. 2019). 
A corrected host plant of Astrotischeria ochrimaculosa. From a morphological point of view, Astrotischeria ochrimaculosa Diškus, Stonis \& Vargas is an outstanding species occurring in Colombia and Peru. In a recent paper on the first discovery of Tischeriidae in Colombia (Stonis et al.2019), we stated that "the larvae of this species mine the leaves of Abutilon Mill., possibly A. divaricatum Turcz. (Malvaceae: Malvoideae: Malvea)." The plant (Figs 140-142) was identified by the research botanist Francisco Fajardo Gutiérrez (Herbarium of Jardín Botánico de Bogotá) based on photographs, and therefore, was provisional. We are grateful to Dr. José Luis Fernández Alonso (Royal Botanical Garden RJB-CSIC, Madrid, Spain) for the re-identification: the host plant of A. ochrimaculosa is Wissadula Medik.: possibly W. amplissima (L.) R.E. Fr. or W. excelsior (Cav.) C. Presl., Malvaceae. José Luis Fernández Alonso also thinks that if there is no herbarium sample or better photographs it would be difficult to identify the host plant with full certainty at the species level. Nevertheless, in our opinion, Wissadula (not Abutilon) is the genus of the host plant. Therefore, we are making the correction of the host plant. Larvae of Astrotischeria ochrimaculosa produce leaf mines on Wissadula in June and probably early in the year; voltinism is unknown. The blotch mine is irregular; in fully developed mines the margin of the mined leaf is distorted (Figs 143-145).

Predicting tischeriid distribution through host-plant distribution. The following seventeen host-plant families are known hosts for the Tischeridae family worldwide: Euphorbiaceae, Fabaceae, Rosaceae, Rhamnaceae, Fagaceae, Betulaceae, Ulmaceae, Urticaceae, Malvaceae (including former Sterculiaceae), Combretaceae, Ericaceae, Symplocaceae, Anacardiaceae, Theaceae, Hypericaceae, Apocynaceae, and Asteraceae (Xu et al. 2018). One of the most pronounced and well-known trophic particularities of Tischeriidae is their narrow diet breadth (stenophagy), they are either monophagous or oliphagous both strict and broad. Currently, most Neotropical Tischeridae species are known only from a single locality. We hypothesize that the distribution of the host plants suggest much broader ranges for these host-specific leaf-miners, including the new species described in this paper.

Coptotriche parvisacculata is currently known only from the single locality, Buenos Aires, Argentina, but feeds on Terminalia australis Cambess. (Combretaceae). Terminalia australis, or palo amarillo, is a southern South American tree species. It forms part of the communities typical of gallery forests and riverine scrub forests along the Paraná and Uruguay rivers and their tributaries, adapted to periodical floods (Apodaca et al. 2019). We expect this tischeriid species to also occur in Brazil, Paraguay, and Uruguay.

Astrotischeria bacchariphaga is currently known only from the single locality in Ecuador, Baños, and feeds on Baccharis emarginata (Ruiz \& Pav.) Pers. and B. latifolia (Ruiz \& Pav.) Pers. (Asteraceae). Both are Andean South American shrubs. Baccharis emarginata, locally known as taya macho or tayango, is restricted to Ecuador and Peru, inhabiting xerophyllous forests (Neil \& Ulloa Ulloa 2011; Galán de Mera et al. 2015), but B. latifolia, locally known as ancochuta or chilca, occurs frequently in the eastern slopes of the Andes from Colombia to northwestern Argentina (Cabrera 1960, 1978). Like Coptotriche parvisacculata, we expect Astrotischeria bacchariphaga to be more broadly distributed from Colombia, south to Peru, and to northern Argentina.

\section{Acknowledgements}

We are indebted to our Ecuadorian scientific partners, including those who participated in the initial project in 1999 by R. Puplesis and S. R. Hill, with Professor Giovanni Onore, a former professor at the Pontifical Catholic University of Ecuador, Quito, Ecuador. We thank the Consejo Nacional de Areas Protegidas (CONAP) Guatemala, C.A. for the Licencia de Collecta o Aprovechamiento de Vida Silvestre (No. 12900) and the Autoridad Nacional de Licencias Ambientales, Bogotá, Colombia, for Collecting Permit No. 2019007511-1-000. Julia Puplesyte-Chambers thanks the Environmental Programme at the Andes Office of NGO DAR Peru for permission to attend training courses and fieldwork on the project "Rapid assessment of biodiversity plots of critical value in the provinces Chanchamayo and Satipo, Peru", in cooperation with the Baltic-American Biotaxonomy Institute in 2017-2018.

The identification of Wissadula, a host-plant genus of Astrotischeria ochrimaculosa by Dr. José Luis Fernández Alonso (Royal Botanical Garden RJB-CSIC, Madrid, Spain) was greatly appreciated. We are also grateful to Dr. Donald Davis and Dr. M. Alma Solis, an expert in the field and a reviewer (Systematic Entomology Laboratory, ARS, USDA and United States National Museum of Natural History, Smithsonian Institution, Washington, D.C., USA) for her useful remarks and suggestions.

This research was partially funded by a grant (S-MIP-19-30, "DiagnoStics") from the Research Council of Lithuania. Andrius Remeikis is also grateful to the Lithuanian Research Council for the research stipend he was awarded in 2019. 


\section{References}

Apodaca, M.J., Katinas, L. \& Guerrero, E.L. (2019) Hidden areas of endemism: small units in the southern Neotropics. Systematics and Biodiversity, 27 (5), 425-438. https://doi.org/10.1080/14772000.2019.1646833

Cabrera, A.L. (1978) Compositae. In: Cabrera, A.L. (Ed.), Flora de la Provincia de Jujuy, República Argentina. Colección Científica del INTA, Buenos Aires, pp. 9-726.

Cabrera, A.L. (1960) Notas sobre tipos de Compuestas sudamericanas en herbarios europeos. III. Los tipos de Ruiz y Pavón. Boletín de la Sociedad Argentina de Botánica, 8, 195-215.

Diškus, A. \& Stonis, J.R. (2012) Leaf-mining insects of Lithuania. The Nepticulidae (Lepidoptera): taxonomy, chorological composition and trophic relationships. Monograph. Lututë Publishers, Kaunas, 220 pp. [in Lithuanian]

Diškus, A. \& Stonis, J.R. (2015) Astrotischeria neotropicana sp. nov. - a leaf-miner on Sida, Malvaceae, currently with the broadest distribution range in the Neotropics (Lepidoptera, Tischeriidae). Zootaxa, 4039 (3), 456-466. https://doi.org/10.11646/zootaxa.4039.3.5

Fundo San Jose (2019) Available from: https://www.fundosanjose.com.pe/en-gb (accessed 16 June 2019)

Galán de Mera, A., Sánchez Vega, I., Montoya Quino, J., Linares Perea, E., Campos de la Cruz, J. \& Vicente Orellana, J.A. (2015) La vegetación del norte del Perú: de los bosques a la jalca en Cajamarca. Acta Botanica Malacitana, 40, 157-190. https://doi.org/10.24310/abm.v40i0.2505

Neill, D.A. \& Ulloa, C. (2011) Adiciones a la Flora del Ecuador. Segundo Suplemento, 2005-2010. Fundación Jatun Sacha, Quito, 202 pp.

Puplesis, R. \& Diškus, A. (2003) The Nepticuloidea \& Tischerioidea (Lepidoptera) — a global review, with strategic regional revisions. Monograph. Lutute, Kaunas, 512 pp, figs. 612.

Stonis, J.R. \& Diškus, A. (2008) Checklist of American Coptotriche (Insecta: Lepidoptera: Tischeriidae) with descriptions of two new species from the tropical forest of Belize (Central America). Zoological Science, 25 (1), 99-106. https://doi.org/10.2108/zsj.25.99

Stonis, J.R., Diškus, A., Carvalho Filho, F. \& Lewis, O.T. (2018) American Asteraceae-feeding Astrotischeria species with a highly modified, three-lobed valva in the male genitalia (Lepidoptera, Tischeriidae). Zootaxa, 4469 (1), 1-69. https://doi.org/10.11646/zootaxa.4469.1.1

Stonis, J.R., Diškus, A., Paulavičiūtè, B. \& Monro, A.K. (2017) Urticaceae-feeders from the family Tischeriidae: descriptions of two new species and new genus Paratischeria gen. nov. Biologija, 63 (1), 1-22. https://doi.org/10.6001/biologija.v63i1.3470

Stonis, J.R., Diškus, A., Remeikis, A. \& Navickaite, A. (2014) Study methods of Nepticulidae: micro-mounts of genitalia structures. In: Stonis, J.R., Hill, S.R., Diškus, A. \& Auškalnis, T. (Eds.), Selected abstracts and papers of the First Baltic International Conference on Field Entomology and Faunistics. Edukologija Publishers, Vilnius, pp. 32-35.

Stonis, J.R., Diškus, A. \& Vargas, S.A. (2019) Discovery of leaf-mining Tischeriidae (Lepidoptera) in Colombia and their distribution in the Neotropics. Zootaxa, 4638 (2), 219-2360. https://doi.org/10.11646/zootaxa.4638.2.3

Xu, J., Dai, X., Liu, P., Bai, H., Diškus, A. \& Stonis, J.R. (2017) First report on Paratischeria from Asia (Lepidoptera: Tischeriidae). Zootaxa, 4350 (2), 331-344. https://doi.org/10.11646/zootaxa.4350.2.8

Xu, J., Dai, X., Liao, C., Diškus, A. \& Stonis, J.R. (2018) Discovery of Ulmaceae-feeding Tischeriidae (Lepidoptera, Tischerioidea), Tischeria ulmella sp. nov., and the first report of the Quercus-feeding T. naraensis Sato in China. Zootaxa, 4399 (3), 361-370.

https://doi.org/10.11646/zootaxa.4399.3.6 